\title{
Clinical and methodological aspects on perineal laceration diagnostics at childbirth
}

\author{
Sofia Pihl
}

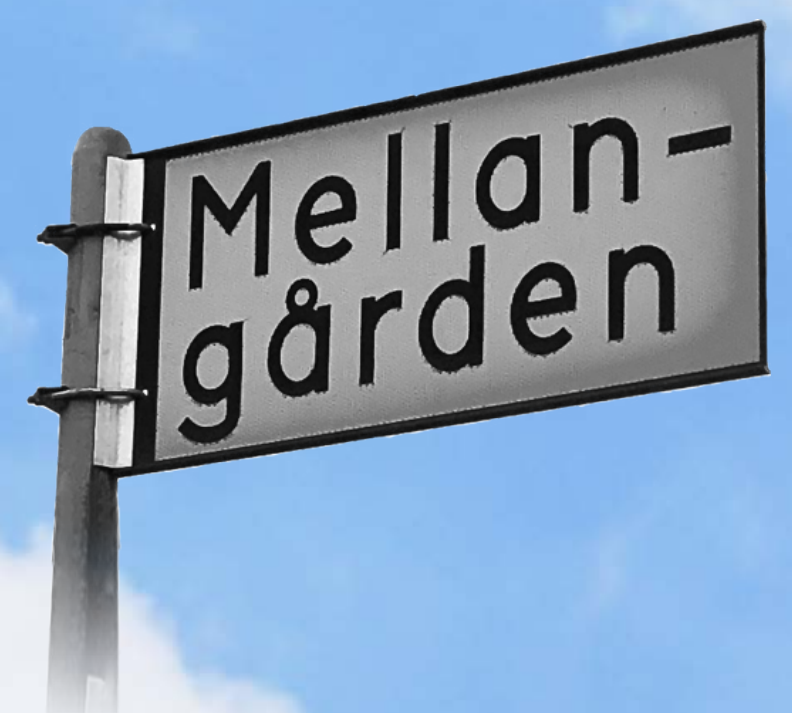

LINKÖPING

UNIVERSITY 


\title{
Clinical and methodological aspects on perineal laceration diagnostics at childbirth
}

\author{
Sofia Pihl
}

Department of Obstetrics and Gynecology

Department of Clinical and Experimental Medicine

Linköping University, Linköping, Sweden

Linköping 2020 
Clinical and methodological aspects on perineal laceration diagnostics at childbirth

(c) Sofia Pihl 2020

Printed by LiU-Tryck, Linköping, Sweden, 2020

ISBN 978-91-7929-962-0

ISSN 0345-0082 
"When compared to the hands the sphincter ani is far superior. If you place into your cupped hands a mixture of fluid, solid and gas and then, through an opening at the bottom try to let only the gas escape you will fail. Yet the sphincter ani can do it. The sphincter apparently can differentiate between solid, fluid, and gas. It apparently can tell whether the owner is alone or with someone, whether standing up or sitting down, whether its owner has his pants on or off.

No other muscle in the body is such a protector of the dignity.

A muscle like that is worth protecting."

Walter C. Bornemeier (1) former president of the American Medical Association 



\section{ABSTRACT}

Background: Obstetric perineal lacerations are common after vaginal birth. The degree of obstetric perineal laceration is defined by the extent of tissue involved in the laceration. When a perineal laceration has occurred after vaginal delivery, the examination for correct diagnostics is essential before primary suturing.

Standard immediate postpartum care is an inspection and palpation of the obstetric perineal laceration.

The aim of this thesis was to explore the diagnostics of obstetric perineal lacerations, and to examine how the methods of bidigital perineal palpation and transperineal ultrasound postpartum can contribute to the clinical diagnostic decisions before primary repair.

Material and Methods: Study I is a methodological study of the learning curve of transperineal ultrasound of the anovaginal distance. The interobserver agreement of the method is also studied between three examiners in an out-clinic gynaecological setting.

Study II is a prospective observational study of 150 primiparous women with suspected perineal laceration of degree 2-3 immediately after childbirth. The study examines the association between bidigital palpation of the perineal height, the anovaginal distance and the final diagnosis of the perineal laceration. Study III is a retrospective observational study with data from the Swedish national Perineal Laceration Registry, studying maternal and obstetric risk factors for internal anal sphincter injury in 3,333 women with external sphincter injury. Study IV is a follow-up study focusing on the implementation strategies and outcome when introducing a new method, (the Diagnostics After DELivery - DADEL concept) for examining perineal lacerations at a maternity ward. The DADEL concept consists of a combination of bidigital palpation of the perineal tissues and transperineal ultrasound in order to determine the degree of perineal lacerations.

Results and conclusions: In study I, the method of transperineal ultrasound measurement of anovaginal distance revealed a short learning period for examiners with previous experience in ultrasound examination. 
The measurements showed high inter-observer agreement. This indicated that the method can be taught and reliably used in further research and clinical practice.

Anovaginal distance was further evaluated in study II, where women with a diagnosis of external sphincter injury had a shorter anovaginal distance compared to women without this injury. The palpatory perineal thickness measured by the midwife was associated with the measurement of the transperineal ultrasound of the anovaginal distance.

With data from the Perineal Laceration Registry, it was shown that $33 \%$ of primiparous women with an external anal sphincter injury also had an internal anal sphincter injury diagnosed immediately after delivery. When the infant was born with a hand or arm beside the head, there was an increased risk for internal anal sphincter injury. Other known risk factors associated with external anal sphincter injury could not be confirmed as independent additional risk factors for internal anal sphincter injury, such as infant weight, duration of delivery or instrumental delivery. Concerning diagnostic methods in the immediate postpartum period, a perineal palpatory thickness of less than $10 \mathrm{~mm}$ was significantly associated with an internal anal sphincter injury when compared with a palpatory thickness of $20 \mathrm{~mm}$ or more.

In the follow-up study of diagnostic methods, it was shown that five years after introduction of the DADEL concept, bidigital palpation is in clinical use to a significantly higher extent than before the initiation of implementation activities. The use of transperineal ultrasound showed no significant change during the same time period. 


\section{LIST OF SCIENTIFIC PAPERS}

I. Interobserver agreement in perineal ultrasound measurement of the anovaginal distance: a methodological study. Sofia Pihl, Eva Uustal, Linda Hjertberg and Marie Blomberg Int Urogynecol J 2018;29:697-701.

II. Anovaginal distance and obstetric anal sphincter injury: a prospective observational study.

Sofia Pihl, Eva Uustal and Marie Blomberg Int Urogynecol J 2019;30:939-44

III. Internal anal sphincter injury in the immediate postpartum period; prevalence, risk factors and diagnostic methods in the Swedish Perineal Laceration Registry.

Sofia Pihl, Marie Blomberg and Eva Uustal

Manuscript submitted.

IV. Palpation and ultrasound of obstetric lacerations implementation and evaluation of adoption of the Diagnostics After DELivery (DADEL) concept.

Sofia Pihl, Siw Carlfjord, Eva Uustal and Marie Blomberg Manuscript submitted.

The published papers are reprinted by permission of the publishers. 



\section{ABBREVIATIONS}

$\begin{array}{ll}\text { AVD } & \text { Anovaginal Distance } \\ \text { BMI } & \text { Body Mass Index } \\ \text { CI } & \text { Confidence Interval } \\ \text { DADEL } & \text { Diagnostics After DELivery } \\ \text { EAS } & \text { External Anal Sphincter } \\ \text { EMR } & \text { Electric Medical Record } \\ \text { GDPR } & \text { General Data Protection Regulation } \\ \text { GynOp } & \text { Swedish National Quality Register of Gynecological Surgery } \\ \text { IAS } & \text { Internal Anal Sphincter } \\ \text { ICD } & \text { International Classification of Disease } \\ \text { OASIS } & \text { Obstetric Anal Sphincter Injuries } \\ \text { OR } & \text { Odds Ratio } \\ \text { PCB } & \text { Paracervical Block } \\ \text { PLR } & \text { Perineal Laceration Registry } \\ \text { RCOG } & \text { Royal College of Obstetricians \& Gynaecologists } \\ \text { SFOG } & \text { Swedish Society of Obstetrics and Gynecology } \\ \text { WHO } & \text { World Health Organization }\end{array}$





\section{CONTENTS}

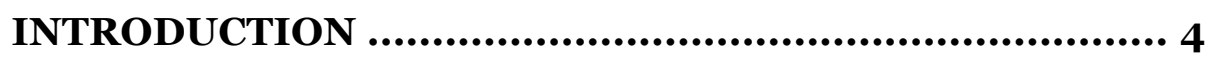

BACKGROUND ......................................................... 6

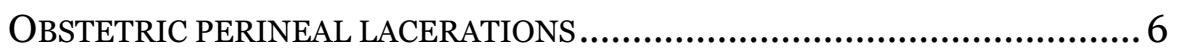

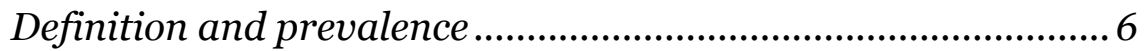

Anatomy and function ............................................................ 8

Risk factors for third-degree perineal lacerations .................... 10

Long-term effects of third-degree lacerations .......................... 13

DIAGNOSTICS OF OBSTETRIC PERINEAL LACERATIONS............................ 14

Standard procedure .................................................................... 14

Ultrasound of the pelvic floor ...................................................15

National perspectives of obstetric lacerations .......................... 18

International perspectives of OASIS ......................................... 19

IMPLEMENTATION OF NEW METHODS IN CLINICAL PRACTICE ...............20

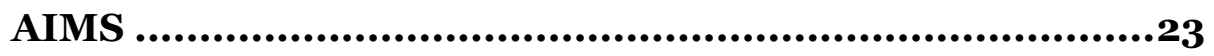

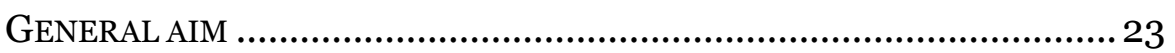

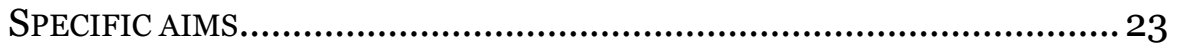

MATERIAL AND METHODS ..................................25

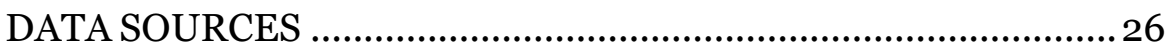

Electronic medical records.................................................26

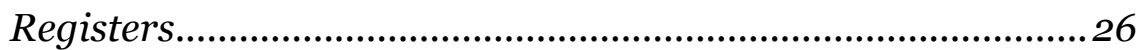

STUDY POPULATIONS AND STUDY DESIGNS ........................... 27

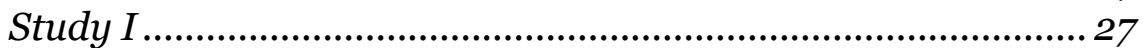

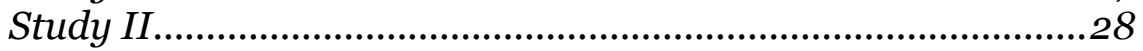

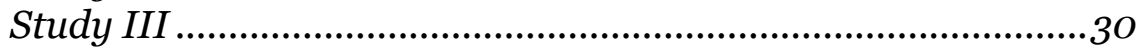

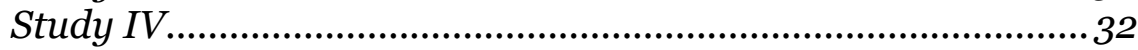

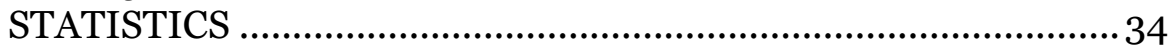

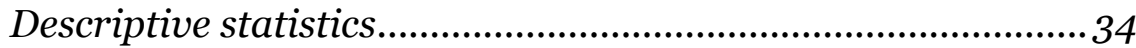

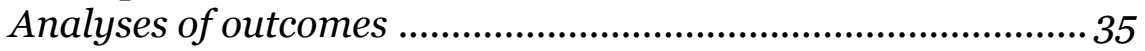

ETHICAL APPROVAL AND CONSIDERATIONS ........................ 37

RESULTS...................................................... 38

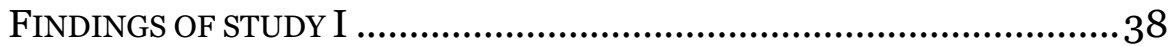

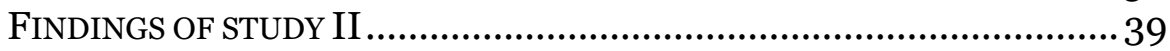

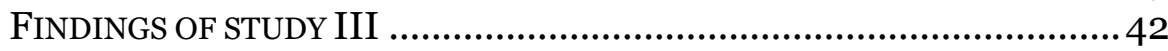

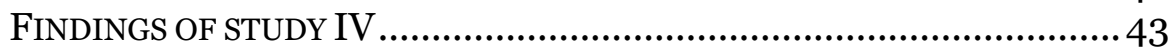

DISCUSSION .....................................................45 
METHODOLOGICAL DISCUSSION

DISCUSSION OF FINDINGS IN STUDIES I-IV AND CLINICAL

IMPLICATIONS

CONCLUSIONS.........................................................55

FUTURE PERSPECTIVES ...........................................55

POPULÄRVETENSKAPLIG SAMMANFATTNING ...........57

ACKNOWLEDGEMENTS ...................................... 60

REFERENCES...........................................................62

PAPERS I-IV ....................................................... 69 


\section{INTRODUCTION}

Obstetric perineal lacerations after vaginal birth occur in $53-79 \%$ of primiparous women $(2,3)$. These can be minor, where only the mucosa of the vagina and the superficial tissues of the perineum is involved, or more extended, where the perineal body, muscles of the pelvic floor and the anal sphincters can be ruptured. The diagnosis of the laceration is based on the perineal tissues involved in the injury.

When a perineal laceration occurs, it should be examined immediately after childbirth and the diagnosis should be decided before primary suturing. In Sweden, the midwife responsible for the childbirth initially performs the examination of the laceration. The examination usually consists of an inspection of the vagina and perineum with the woman in the lithotomy position, followed by palpation of the area in order to investigate whether the anal sphincters are involved in the laceration or not. It is recommended to always provide adequate anaesthesia, often a pudendal block, before the examination (4).

If an anal sphincter involvement is suspected, the physician on call should be consulted and asked to perform a further examination and repair of the laceration.

It is recommended to perform a thorough perineal examination after childbirth; however, the methods for diagnosing the degree of perineal laceration are not suggested in earlier studies or international recommendations, nor are there guidelines on determining when a senior clinician should be involved in the diagnostic process. This allows for an unjustified variation in practice.

The examination of a perineal laceration is often perceived as difficult, due to oedema and bleeding directly after childbirth and sometimes challenging anatomical conditions.

Distinguishing an isolated perineal laceration from an anal sphincter injury in the acute phase has to be performed with high diagnostic consistency at all times to prevent the long-term complications of an undiscovered sphincter injury. Long-term consequences such as perineal pain, gas- or faecal-incontinence that cause disabilities and inconvenience for the woman might thereby be avoided. 
Studies have shown that undiagnosed, occult, sphincter injuries exist, either as an unidentified anal sphincter tear, insufficient repair of a correctly diagnosed injury, or tear of the sutures after repair of the injury $(2,5)$. To avoid this, both the perceptions and knowledge about clinical signs of anal sphincter injury should be increased in clinical practice and examined and documented orderly. The language used when describing obstetric lacerations needs to be more objective to make it easier for the physician on call to know what signs to react to and what to do. 


\section{BACKGROUND}

\section{Obstetric perineal lacerations}

\section{Definition and prevalence}

The degree of obstetric perineal laceration is defined by the extent of tissue involved in the laceration (table 1).

A first-degree laceration is a superficial laceration in the perineal skin or the vaginal mucosa.

A second-degree laceration extends into the perineal tissues and involves the muscles of the pelvic floor such as the musculus transversus perinei and musculus bulbocavernosus, also called the bulbospongiosus muscle. These can be superficial and in the lower (caudal) part of the vagina or can stretch all the way up to the cervical fornix and still be defined as degree 2 . This kind of laceration always needs suturing to heal properly.

When an episiotomy has been performed, it is classified as at least degree 2 , consistent with this definition.

Degree 3 and 4 involve the anal sphincter complex and are considered as large perineal lacerations.

A degree 3 laceration includes the external anal sphincter (EAS) and should be defined as $3 \mathrm{~A}$ if less than half the sphincter is torn or $3 \mathrm{~B}$ if more than half of the muscle is ruptured. If the internal anal sphincter is injured, it is defined as $3 \mathrm{C}$.

When the laceration stretches through the anorectal mucosa, it is classified as degree 4 . In these cases, the external and internal anal sphincter should always be considered as injured too.

Superficial lacerations of the anal skin are known for causing diagnostic intricacies. If the laceration remains caudal to the linea dentata, it should be defined as a degree 3 laceration. If the laceration extends more cranial from the linea dentate, it is defined as a degree 4 laceration. The linea dentata (6) is where the embryological junction between the endoderm (columnal epithelium) and the ectoderm (stratified squamous epithelium) is made. The misunderstanding that even the most caudal anal skin injury is defined as a degree 4 laceration might result in a slightly erratic higher frequency of fourth-degree lacerations than intended.

If the skin and perineum are intact, it is still important to conduct a thorough rectal examination since a hole can appear in the anorectal 
mucosa above the sphincter complex and lower perineal segment (a buttonhole tear). This is a diagnostic challenge, but very important to find, as it represents a risk of fistula development if undetected.

\begin{tabular}{|c|c|}
\hline Type of tear & Definition \\
\hline First degree tear & Injury to perineal skin \\
\hline Second degree tear & $\begin{array}{l}\text { Injury to perineum involving perineal muscles but not involving the } \\
\text { anal sphincter }\end{array}$ \\
\hline Third degree tear & Injury to the perineum involving the anal sphincter complex \\
\hline $3 \mathrm{~A}$ & Less than $50 \%$ of external anal sphincter thickness torn \\
\hline 3B & More than $50 \%$ of external anal sphincter thickness torn \\
\hline $3 \mathrm{C}$ & Both external and internal anal sphincter torn \\
\hline Fourth degree tear & $\begin{array}{l}\text { Injury to perineum involving the anal sphincter complex (both } \\
\text { external and internal anal sphincter) and anorectal mucosa. }\end{array}$ \\
\hline Buttonhole tear & $\begin{array}{l}\text { External anal sphincter intact but anorectal mucosa with or without } \\
\text { internal anal sphincter tear }\end{array}$ \\
\hline
\end{tabular}

Table 1. Classification of perineal lacerations (7).

This classification of perineal lacerations is from the International Classification of Disease (ICD) by the World Health Organization $(\mathrm{WHO})(7)$. This definition of obstetric perineal lacerations was adapted in 
Sweden in 2014. This was the first diagnostic classification where the internal anal sphincter is mentioned.

In Sweden, the prevalence of degree 1-2 lacerations is not known or registered. In 2017, $5.2 \%$ of all primiparous women and $1.3 \%$ of all multiparous women had a degree 3 or 4 laceration (8).

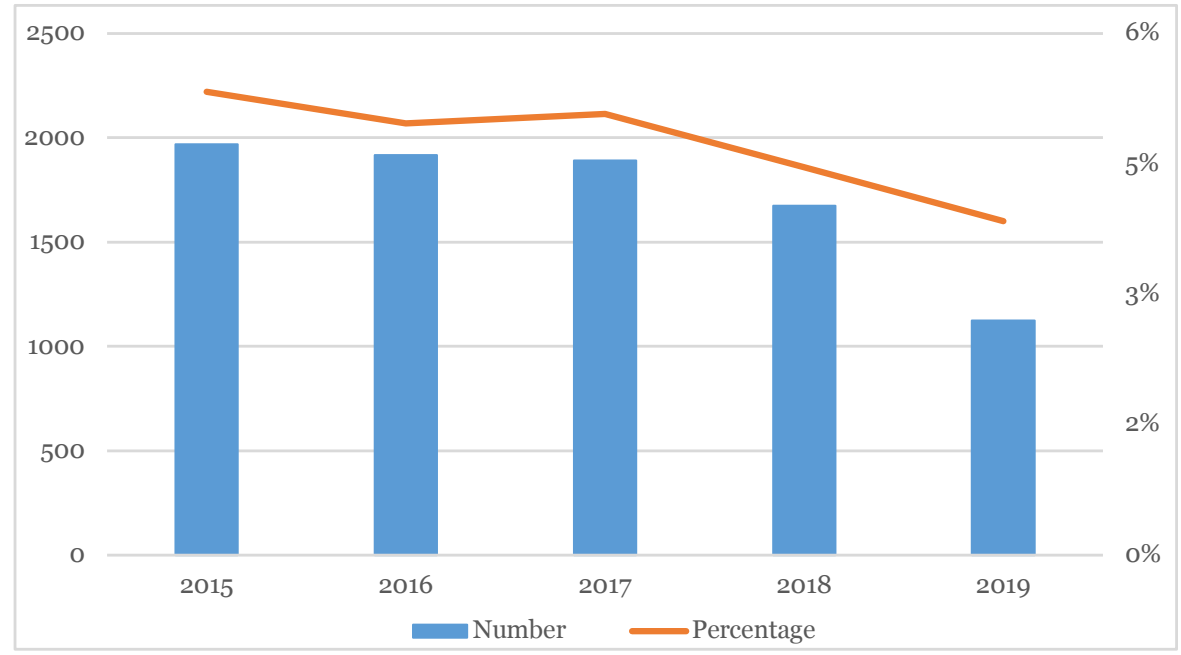

Figure 1. Perineal lacerations degree 3-4, primiparous women in Sweden 2015-2019 (9).

\section{Anatomy and function}

The perineal body is situated between the vagina and the anal canal. It consists of dense connective tissue involving superficial and deep muscles of the perineal membrane (10), including the transverse perineal muscle, the puborectalis muscle and attachments of the bulbospongiosus muscle $(11,12)$. The muscles of the pelvic floor all attach to the perineal body, and their functions depend on each other, like spokes in a wheel (13).

The bulbospongiusus muscle encircles the vaginal introitus and attaches at the clitoris frontally and at the perineal body rectally. The transverse perineal muscle runs from the pelvic bone sideways to the perineal body, and thereby lifts the perineal tissues cranially. The puborectal muscle is the muscle mainly used when contracting the pelvic floor voluntarily and extends from the rear side of the pubic bone and around the anal canal as a sling. This muscle can lift the pelvic floor and the anal canal upwards and frontally. 
Caudal to the perineal body is the anal sphincter complex. This complex includes the internal and external sphincters, encircling the distal anus.

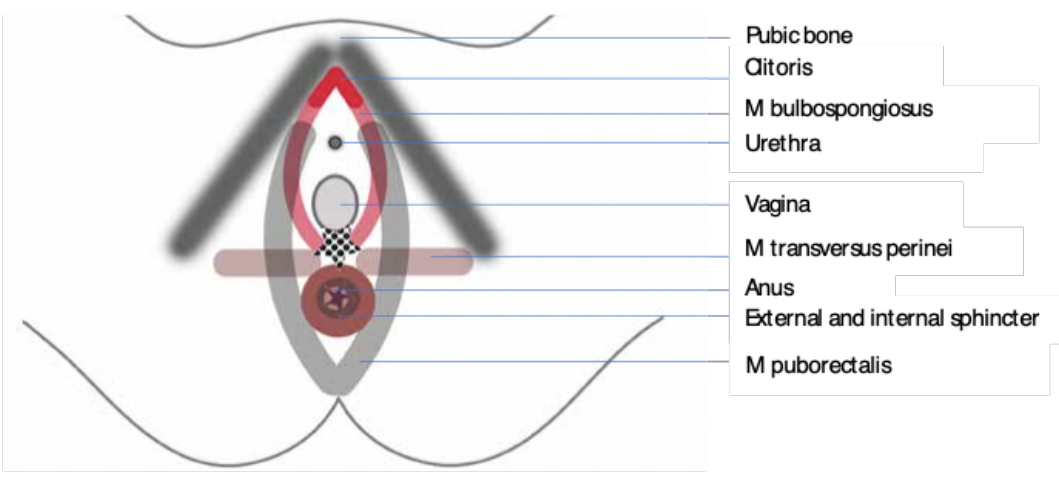

Figure 2. Schematic figure of the female anatomical structures that might be involved in obstetric lacerations (13). Used with permission from Eva Uustal.

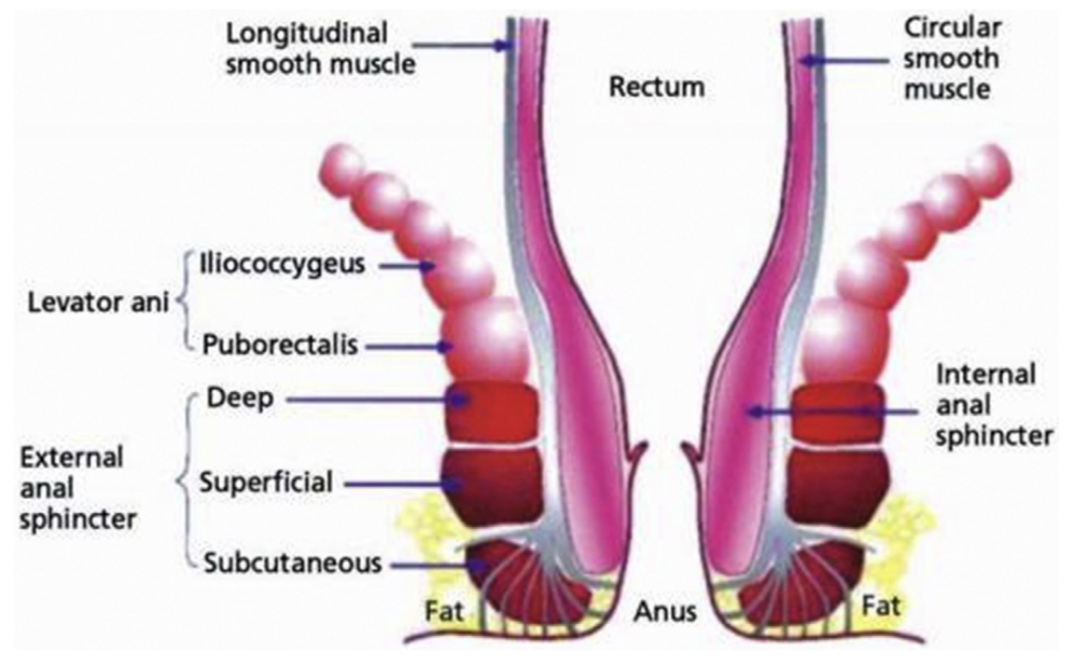

Figure 3. Anatomy of the anal canal, coronary cross section. Reprinted from The Surgeon, 15, Kumar and Emmanuel, Internal anal sphincter: Clinical Perspective, p 211-226, 2017 with permission from Elsevier. 
The external anal sphincter is composed of skeletal muscle. The external anal sphincter is under voluntary control and provides the squeeze pressure of the anal canal.

The internal anal sphincter (IAS) is a ring of smooth muscle, emanating from the intestinal wall and thickening into a sphincter in the anal canal. It ends at the dentate line below which the subcutaneous part of the external sphincter continues. It is usually described to be 2.5 centimetres in the craniocaudal direction and 3-5 millimetres thick. The IAS is dually innervated by the autonomous and enteric nervous system and is thus not under voluntary control. The parasympathetic and sympathetic nervous systems are excitatory and inhibitory, respectively, whereas the enteric nervous system controls the resting tone (6).

The IAS contributes to $50-85 \%$ of the resting anal tone; the rest comes from the vascular anal cushions and the tonus of the external anal sphincter. IAS dysfunction can result in anal incontinence, impaired faecal sampling and faecal urgency (14). The most common cause of low pressure of the IAS is an obstetrical injury (6). In research, the IAS is mostly studied in regard to malformations of the rectum and in oncology. To our knowledge, the internal anal sphincter as a part of obstetric perineal lacerations has not been studied in isolation, but as a part of the sphincter complex.

\section{Risk factors for third-degree perineal lacerations}

The risk factors for obstetric third-degree lacerations have been well studied. A wide range of maternal, obstetric and foetal characteristics and circumstances have been studied, and the most influential and common risk factors are summarised in table 2 .

The strongest obstetric risk factor associated with sphincter involvement is forceps assisted delivery, followed by vacuum assisted delivery $(15,16)$. Another strong risk factor, the midline episiotomy, accentuates the other risks and should be avoided (17). This kind of episiotomy is rare in the European countries but more frequent in North America (18).

The midline episiotomy should not be confused with the mediolateral episiotomy. This is, on the contrary, recommended both in Swedish national recommendations (13) and in the RCOG recommendations (19) in nulliparous women when using a vacuum extraction, as it has shown decreased risk for OASIS (17). In other obstetric situations, the role of episiotomy is unclear, and the proportion of and indications for 
episiotomies differ widely based on clinical traditions both in countries and in regions within a country.

Based on a combination of risk factors, a scoring system for the risk of anal sphincter injury has been studied in order to provide advice on the best method of delivery, but has not been considered clinically applicable (20). Concerning the risk factors for internal sphincter injuries and degree 4 lacerations, research is sparse, and are usually considered to be identical as for OASIS in common. 


\begin{tabular}{|c|c|c|c|}
\hline Risk factor & OR & CI $(95 \%)$ & $\begin{array}{c}\text { Referenc } \\
\text { e }\end{array}$ \\
\hline Primiparity & $\begin{array}{c}3.24 \\
\text { RR } 6.97\end{array}$ & $\begin{array}{c}2.20-4.76 \\
5.40-8.99\end{array}$ & $\begin{array}{l}26 \\
15\end{array}$ \\
\hline $\begin{array}{l}\text { Second vaginal delivery when anal incontinence } \\
\text { after OASIS }\end{array}$ & 11.2 & $1.84-86.2$ & 21 \\
\hline Asian ethnicity giving birth in a western country & $\begin{array}{l}2.27 \\
2.74\end{array}$ & $\begin{array}{c}2.14-2.41 \\
1.31-5.72\end{array}$ & $\begin{array}{l}24 \\
26\end{array}$ \\
\hline Shortened perineal body & $\begin{array}{l}<2,5 \mathrm{~cm} \\
<3 \mathrm{~cm}\end{array}$ & $\begin{array}{l}\text { p } 0.04 \\
\text { p } 0.04\end{array}$ & $\begin{array}{l}22 \\
25\end{array}$ \\
\hline Mother of the woman had OASIS & 1.9 & $1.6-2.3$ & 23 \\
\hline Sister of the woman had OASIS & 1.7 & $1.6-1.7$ & 23 \\
\hline Labor induction & 1.08 & $1.02-1.14$ & 26 \\
\hline Epidural anesthesia & 1.95 & $1.66-2.32$ & 26 \\
\hline Labor augmentation & 1.95 & $1.56-2.44$ & 26 \\
\hline Second stage of labour $>\mathbf{2 h}$ & 1.42 & $1.28-1.58$ & 28 \\
\hline Second stage of labour $>3 \mathrm{~h}$ & 3.20 & $2.62-3.89$ & 27 \\
\hline Forceps-assisted delivery & $\begin{array}{c}5.5 \\
6.53\end{array}$ & $\begin{array}{l}3.17-9.55 \\
5.57-7.64\end{array}$ & $\begin{array}{l}22 \\
24\end{array}$ \\
\hline Vacuum - assisted delivery & $\begin{array}{l}1.89 \\
3.98\end{array}$ & $\begin{array}{l}1.74-2.05 \\
2.60-6.09\end{array}$ & $\begin{array}{l}24 \\
22\end{array}$ \\
\hline Vacuum- assisted delivery with episiotomy & 0.57 & $0.51-0.63$ & 24 \\
\hline Midline episiotomy & 3.82 & $1.96-7.42$ & 22 \\
\hline Midline episiotomy combined with forceps delivery & 5.65 & $5.55-5.75$ & 22 \\
\hline Shoulder dystocia & 1.90 & $1.72-2.08$ & 24 \\
\hline Persistent occiput posterior position & $\begin{array}{l}2.44 \\
3.09\end{array}$ & $\begin{array}{l}2.07-2.89 \\
1.81-5.29\end{array}$ & $\begin{array}{l}15 \\
26\end{array}$ \\
\hline Birth weight over 4 kg & 2.27 & $2.18-2.36$ & 24 \\
\hline
\end{tabular}

Table 2. Summary of described risk factors for obstetric anal sphincter injuries (15, 21-28). OASIS - obstetric anal sphincter injuries. 


\section{Long-term effects of third-degree lacerations}

The reason for studying the risk factors, diagnostics and suturing techniques of OASIS is to avoid the long-term consequences of an undetected, unoptimised sutured, or well sutured but torn anal sphincter injury.

After a primary repair and healing, anal incontinence for gas or faeces ranges between $15-69 \%(19,29)$. Other long-term effects after OASIS are perineal pain, dyspareunia (30) and more unusual abscess formation and anovaginal fistulas.

Living with anal incontinence impairs everyday life in a profound way. Anal incontinence is a disabling complication with social and hygienic problems, isolation, reduced self-confidence and decreased quality of life. Furthermore, it often has a negative impact in physical and mental health, and may lead to limitations in occupational and social activities and in sexual function (31-34).

It has been shown that women with an OASIS have a twofold greater risk of anal incontinence than women with a less extensive perineal laceration, even when the OASIS was properly diagnosed and sutured (35). It has also been shown in interventional studies after primary suturing (2) that occult OASIS exists in $27 \%$ of women $(36,37)$, when re-examined with endoanal ultrasound. A raised awareness and knowledge (38) and a support system of re-examination with another examiner before primary repair seems to increase the rate of overt OASIS (39).

On the other hand, there is need for a certain caution about interpreting endoanal ultrasonographic signs retrospectively $(40,41)$, as women with and without an ultrasonographic scar of the EAS had similar scores in anal incontinence scales. Recent studies suggest the IAS might be more important to long-term anal incontinence and quality of life $(5,41-44)$ than the EAS.

It has been shown that the IAS should be identified and sutured separately for a better postoperative function for the woman (45). Most research on IAS injuries have taken the form of follow-up studies in populations with faecal incontinence, pain, faecal urgency or other perineal problems after an obstetric laceration, whereas no diagnostic studies to our knowledge have been performed immediately after delivery and before primary repair. 


\section{Diagnostics of obstetric perineal lacerations}

\section{Standard procedure}

When a perineal laceration has occurred after vaginal delivery, a proper diagnosis has to be made before primary suturing. To make examination of the area possible, a pudendal block is recommended before palpation (4). The practical recommendations for how to examine a perineal laceration and the criteria for when to ask for diagnostic support are often vague in the guidelines.

When complex lacerations exist or if there is excessive bleeding, optimised positioning, suitable lighting, and assistance facilitate the performing of the repair (18).

In standard immediate postpartum care in the delivery suite the woman undergoes an initial inspection and palpation of the obstetric perineal laceration by the midwife responsible for the delivery. The examination consists of a bidigital palpation with one finger at the bottom of the perineal laceration and one finger in the anal canal. Only the distal phalanx of one index finger is inserted in the anal canal, and the other index finger's distal phalanx is put on the distal posterior vaginal wall. The thickness between the fingertip pads is then assessed. The palpatory thickness of the perineal tissue and observed status of the external and internal anal sphincter are noted, and the physician on duty is called if an anal sphincter injury is suspected or if the extent of the perineal laceration is uncertain.

A bidigital examination with one finger at the bottom of the laceration and one finger in the anal canal is recommended in some guidelines for all women with a perineal laceration $(2,4,19)$ and in some only if the laceration is more than superficial (46), or deep (18). The aims of the examination and the interpretation of findings are however sparsely mentioned, i.e. to properly see the apex of the laceration, inspect the tissues in trying to identify the muscles of the anal sphincters and to assess the thickness of the perineal tissues.

When examining a perineal laceration, identification of the anal sphincters can be difficult, especially the internal sphincter, which is pale, half transparent and cannot be contracted at will. It is stated in recommendations that every attempt should nonetheless be made to exclude and document injury to the IAS (19), but there is no information on how this should be done and by whom. 
When relying on inspection and palpation of the perineal tissues, the interpretation of the examination is subjective and might vary between examiners according to their experience and the situation $(2,39,47)$.

\section{Ultrasound of the pelvic floor}

Endoanal ultrasound is considered the golden standard when diagnosing issues with the anatomy of the perineum and anal sphincters when examining women with anal incontinence.

The use of endoanal ultrasound before or immediately after primary repair postpartum improved the diagnosis of anal sphincter tears and reduced the risk of severe faecal incontinence three months postpartum $(48,49)$. It has been suggested to routinely use endoanal ultrasound of the perineal tissues and anal sphincters immediately after childbirth. However, that requires special endoanal scanners and specialised training to perform safely with high validity. Recent review studies including a Cochrane report $(18,19$, 50) conclude that further studies are necessary to analyse detection rates, costs and training in the method before routine use of endoanal ultrasound postpartum can be recommended in clinical practice. The studies also conclude that if the method is used immediately postpartum it should be considered a research tool.

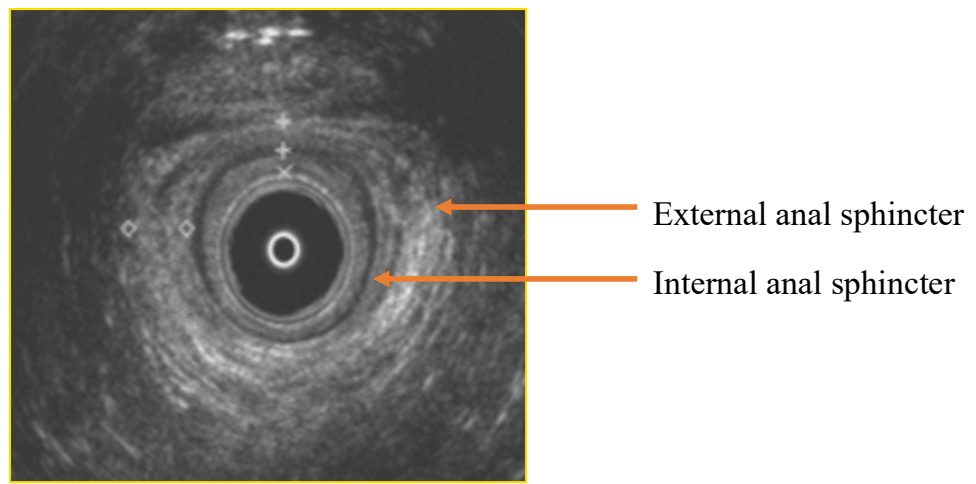

Figure 4. Endoanal ultrasound, intact perineum. Used with permission of Eva Uustal.

Instead of the endoanal ultrasound, alternative ultrasonographic modalities $(51,52)$ of transperineal or transvaginal scanning have been evaluated. Transvaginal ultrasound with vaginal probes and the standard convex 5 $\mathrm{MHz}$ probe is available in most obstetric and gynaecological units of Europe and the staff are already using it in daily practice for other areas in 
obstetrics and gynaecology. To our knowledge, all research on these modalities has studied conditions after primary repair or in long-term follow-up-studies, but no studies have been performed before primary repair. However, in the postpartum period it is stated that transperineal (29, $53,54)$ or transvaginal $(55)$ examination is useful in identifying normal anatomy with high specificity but low sensitivity, especially for endovaginal ultrasound with a rotating probe (43). A few studies have compared the endoanal and transvaginal (56-60) or transperineal (61-64) approaches, suggesting these to be feasible alternatives in clinical practice. However, as the pelvic floor with its three-dimensioned muscle layers and separate anatomical structures is challenging to identify, pelvic floor ultrasound has low inter- and intraobserver agreement (41, 48, 58, 60, 6467 with over- as well as under-diagnosis of lacerations, probably depending on variation in interpretation of images.

The internal anal sphincter is easier to detect with ultrasound than other perineal tissues. Due to its high level of glycogen binding water, it appears as a distinct black ring. We have therefore found it appropriate for bedside ultrasound examination in clinical practice.

Transperineal ultrasound examinations of OASIS shows characteristic signs which correlate well with the clinical complaints of long-term incontinence (68). The advantages of this modality include its wide applicability in clinical practice and acceptability by patients because of its painless and non-intrusive nature. In addition, there is no distortion of the anal canal by the transducer during the examination. A disadvantage that has been stated is that the dorsal part of the anal sphincter complex is difficult to visualise (57), but that is not perceived as clinically relevant when the method is used for obstetric lacerations. Therefore, further research on the clinical applicability and usability would be of interest and motivated this thesis. 


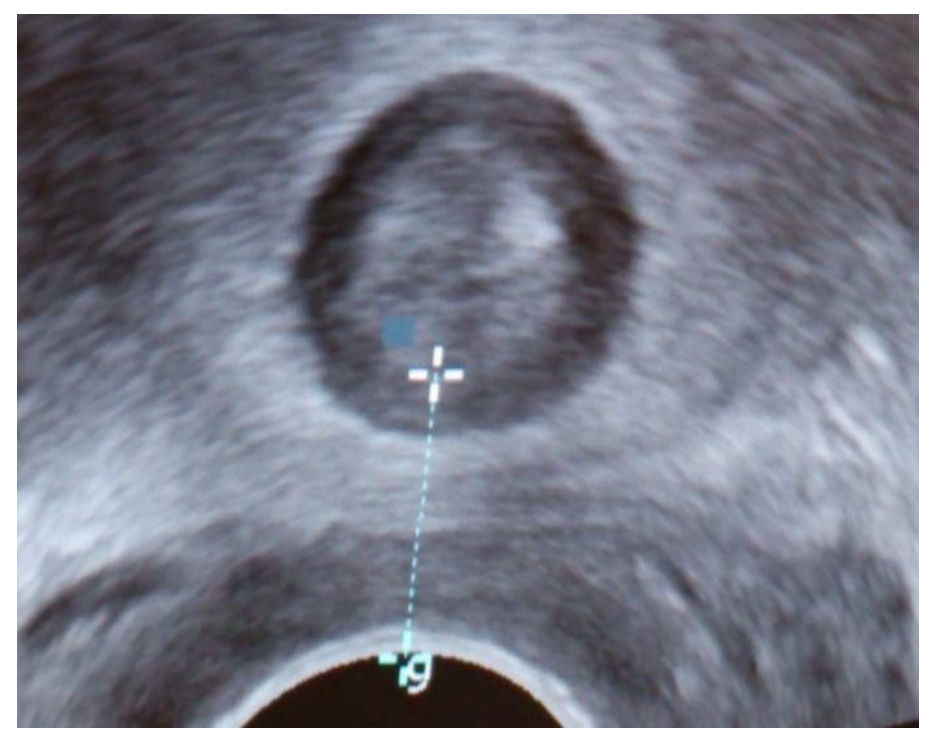

Figure 5. Transperineal ultrasound of the perineal tissues. Intact internal sphincter seen as a dark ring. Anovaginal distance measured between +-+ Picture by the author.

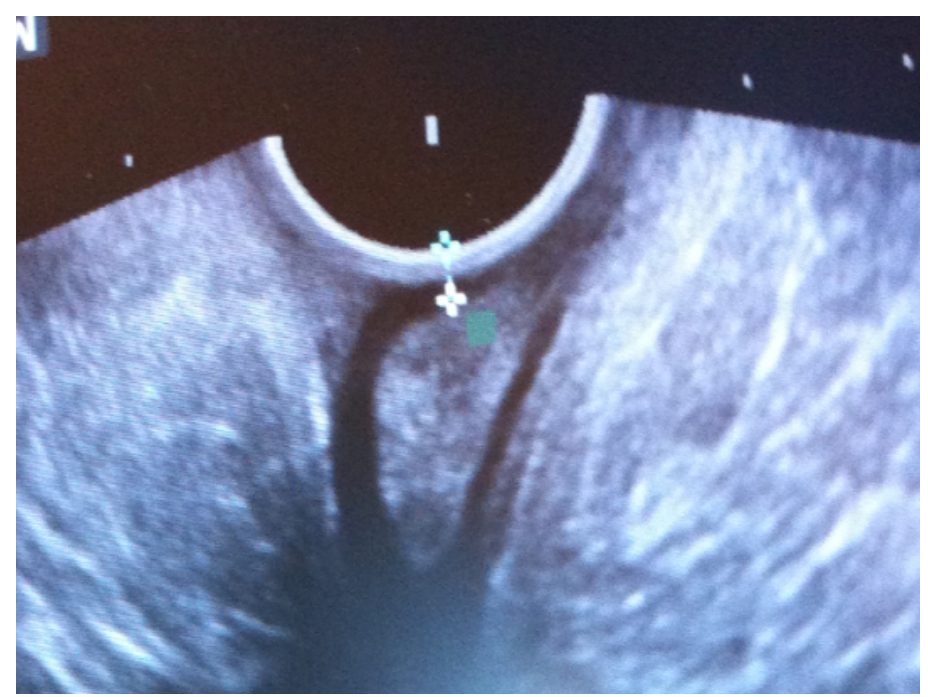

Figure 6. Transperineal ultrasound of the perineal tissues immediately after delivery before suturing. Anovaginal distance $2 \mathrm{~mm}$, rupture of external and internal anal sphincters. Used with permission from Eva Uustal. 


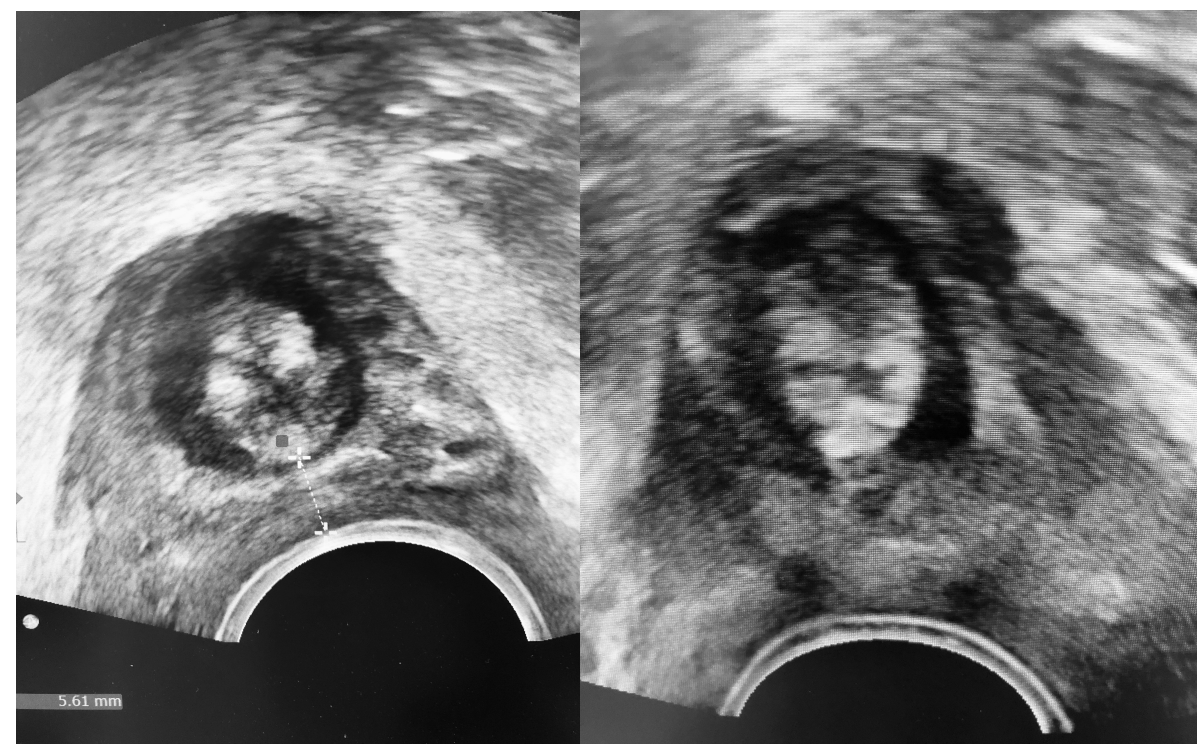

Figure 7. a. Transperineal ultrasound of the attenuated anovaginal distance, measured $5.6 \mathrm{~mm}$ with a thin brim of internal anal sphincter, 6 weeks postpartum.

b. Transperineal ultrasound of interrupted internal anal sphincter (halfmoon sign), 12 weeks postpartum. Pictures by the author.

\section{National perspectives of obstetric lacerations}

In Sweden, the diagnostic codes of perineal lacerations were changed in 2014, making it possible to document an internal anal sphincter injury. Before this change, the rate of IAS was not known.

Two other changes in the last decade have had a widespread impact on health care concerning obstetric lacerations in Sweden.

The first was the introduction of the national Swedish registry of Perineal Lacerations (PLR) in 2014. The PLR is a section of the Swedish National Quality Register of Gynaecological Surgery that has operated since 1997 (69). The PLR covered data from 36 of 45 delivery clinics in Sweden in 2018. Most maternity clinics report degree 3 and 4 lacerations to the PLR, while an increasing number of clinics have chosen to also include women with a second-degree laceration. The PLR provides data for national comparisons and research. The register uses data extracted from medical 
and obstetric records, such as obstetric characteristics and surgical methodological data. The register is described in detail in the methodology section and in study III. As the register includes follow-up questionnaires from the women to the responsible health care personnel conducting the repair, at eight weeks and one year postpartum, individual feedback on the results of reconstruction of the tear is provided to physicians and midwives. This makes it possible to establish contact if the woman has complications or questions and increases awareness of surgical results.

The other change is the introduction of a web based pelvic floor education programme, www.backenbottenutbildning.se (4), only available in Swedish. This was introduced in 2017 by the Swedish Society of Obstetricians and Gynaecologists, the Swedish Association of Midwives, and financed by Landstingens ömsesidiga försäkringsbolag. The education consists of a thorough review of the pelvic floor during delivery including, among others, risk factors for perineal lacerations, management to improve outcome, and surgical techniques. It also contains patient information in different languages and instructional pictures of perineal lacerations and postpartum care for the woman after returning home. The education programme is recommended to all health care personnel working in delivery clinics in Sweden and makes it possible to make the management of perineal lacerations and information to the women more uniform throughout the country.

\section{International perspectives of OASIS}

OASIS incidences are considered difficult to compare due to differences in diagnostic methods, populations and health care routines. Also, remunerations and litigation traditions depending on health care services systems can play a role in diagnosing differently.

In the Nordic countries, which all have well established national birth registries, different traditions can be seen. A study from 2010, comparing the Nordic countries' incidence of OASIS, found a Nordic record in Denmark with $4.2 \%$, followed by Sweden $3.2 \%$ and Norway $2.3 \%$ and the lowest rates in Finland, 1.0\%. In Finland and Norway, episiotomy is more common (20-25\%) than in Denmark and Sweden (5-6\%), which according to this study might, even though the role of episiotomy in OASIS risk varies in different studies, explain the rates in the Nordic countries according to this study (70). 
In many countries, the degree of perineal lacerations is not registered, and therefore is neither known nor studied.

In the US, the National Quality Forum recently withdraw their endorsement of OASIS as a quality indicator of obstetric care, as it is not considered an appropriate measure of value. The reasons behind the decision are the insecure diagnostics and the fact that risk factors are not modifiable with high quality obstetric care but depend on factors associated with childbirth itself. There is a fear that further reduction of instrumental deliveries in order to avoid third-degree tears may lead to an unwanted increase in caesarean section (71). This will be an interesting and disputable point of view for further discussions.

\section{Implementation of new methods in clinical practice}

Traditionally, academic research has struggled with difficulties of how the results of the evidence-based results and recommendations are reacted into everyday use, called the research-practice gap (72). A time interval of 17 years from the study result to routine use in general health care is often mentioned $(73,74)$.

Implementation can be understood as the processes involved in getting an intervention or technique into use and assimilated within an organisation (75). As new techniques and interventions evolve in medical health care, a need for evaluation of formative outcomes and strategies for successful implementation in specific contexts arises (76). Implementation-oriented research could contribute to an increased public health impact for invested research funds; at least this is shown in the American health/research funding system (77).

To optimise user sustainability and promote dissemination in other settings, the identification of supporting and hindering factors is important in every implementation in a new setting (76). A framework developed to identify and assess barriers and facilitators of health intervention implementation is the Consolidated Framework for Implementation Research (CFIR). This meta-theoretical framework was constructed to answer the question of 'what works where and why', and is organised into five domains (intervention characteristics, outer setting, inner setting, characteristics of individuals and implementation process). The CFIR has been widely utilised to evaluate implementation studies (78-80), and will be applied in 
this study for the evaluation analysis and discussion of implementation outcome.

Multiple strategies for implementation are available, but the reporting of implementation studies has been criticised for inconsistency in the use of terminology. To avoid this, the description of strategies used in the present study was inspired by the compilation of implementation strategies presented in the Expert Recommendations for Implementing Change (ERIC) project (81).

When planning this thesis, the aim was to explore whether a structured combination of the examination methods used in clinical practice could facilitate diagnostics of obstetric perineal lacerations and enable a comparison of outcomes to facilitate learning. Research on the immediate assessment, diagnostics and decision-making on perineal lacerations after childbirth before primary suturing is infrequent, compared to follow-upstudies in women with long-term complications after an anal sphincter injury or other laceration. This might be due to the ethical circumstances of performing studies immediately after childbirth but is nevertheless important for preventing long-term complications. 


\section{AIMS}

\section{General aim}

- To explore the diagnostics of obstetric perineal lacerations, and how the methods of bidigital perineal palpation and transperineal ultrasound postpartum can contribute to the clinical decisions before primary repair.

\section{Specific aims}

- to evaluate the use of transperineal ultrasonography for measuring the anovaginal distance, in terms of both ease of learning by the examiner and interobserver agreement. (Study I)

- to evaluate whether there is a relation between the anovaginal distance measured with transperineal ultrasound after delivery and diagnosed external anal sphincter injury. (Study II)

- to assess whether the initial bidigital examination of the perineum was associated with the anovaginal distance measured with transperineal ultrasound. (Study II)

- to assess the proportion of internal anal sphincter injury immediately postpartum in women with an external anal sphincter injury and to evaluate maternal and obstetric risk factors for internal anal sphincter injury compared to external anal sphincter injury only. (Study III)

- to relate the diagnostic methods of obstetric anal sphincter injury to the presence of an internal anal sphincter injury. (Study III)

- to describe implementation strategies used when establishing the diagnostics after delivery (DADEL)-concept for diagnosing obstetric perineal lacerations at a maternity ward and to evaluate implementation outcome in terms of use of components of the method before, directly after and 5 years after initial implementation. (Study IV) 


\section{MATERIAL AND METHODS}

A brief overview of the subjects and methods of the four studies is presented in table 3 .

Table 3. Overview of the studies included in the thesis

\begin{tabular}{|c|c|c|c|c|}
\hline PAPER & $\mathbf{I}$ & II & III & IV \\
\hline $\begin{array}{l}\text { Study } \\
\text { design }\end{array}$ & $\begin{array}{l}\text { Methodological } \\
\text { study }\end{array}$ & $\begin{array}{l}\text { Prospective } \\
\text { observational study }\end{array}$ & $\begin{array}{l}\text { Population based } \\
\text { observational } \\
\text { cohort study }\end{array}$ & $\begin{array}{l}\text { Follow-up study after } \\
\text { implementation }\end{array}$ \\
\hline Years & 2013-2014 & 2014-2016 & 2014-2018 & 2014-2019 \\
\hline $\begin{array}{l}\text { Data } \\
\text { sources }\end{array}$ & $\begin{array}{l}\text { Electronic } \\
\text { medical records }\end{array}$ & $\begin{array}{l}\text { Electronic medical } \\
\text { records }\end{array}$ & $\begin{array}{l}\text { Swedish Perineal } \\
\text { Laceration Registry }\end{array}$ & Electronic medical records \\
\hline $\begin{array}{l}\text { Study } \\
\text { populatio } \\
\text { n }\end{array}$ & $\begin{array}{l}40 \text { women at a } \\
\text { gynecological } \\
\text { outpatient } \\
\text { clinic }\end{array}$ & $\begin{array}{l}150 \text { primiparous } \\
\text { women with } \\
\text { suspected perineal } \\
\text { laceration degree } \\
2-3 \text { immediately } \\
\text { after childbirth }\end{array}$ & $\begin{array}{l}3333 \text { primiparous } \\
\text { women with } \\
\text { perineal laceration } \\
\text { degree } 3-4 .\end{array}$ & A maternity ward \\
\hline $\begin{array}{l}\text { Exposure } \\
\text { s/Interven } \\
\text { tions }\end{array}$ & $\begin{array}{l}\text { Transperineal } \\
\text { ultrasound } \\
\text { measurement } \\
\text { of the } \\
\text { anovaginal } \\
\text { distance }\end{array}$ & $\begin{array}{l}\text { Anovaginal } \\
\text { distance measured } \\
\text { with transperineal } \\
\text { ultrasound }\end{array}$ & $\begin{array}{l}\text { Maternal and fetal } \\
\text { characteristics, } \\
\text { obstetric variables, } \\
\text { diagnostic methods. }\end{array}$ & $\begin{array}{l}\text { Quantitative bidigital } \\
\text { palpation and transperineal } \\
\text { ultrasound in the DADEL- } \\
\text { concept. }\end{array}$ \\
\hline Outcome & $\begin{array}{l}\text { Interobserver } \\
\text { agreement of } \\
<5 \mathrm{~mm}\end{array}$ & $\begin{array}{l}\text { I. External } \\
\text { sphincter injury } \\
\text { II. Bidigital } \\
\text { palpation } \\
\text { measurement }\end{array}$ & $\begin{array}{l}\text { Internal anal } \\
\text { sphincter injury }\end{array}$ & $\begin{array}{l}\text { Clinical use of } \\
\text { recommendations before, } \\
\text { immediately after and } 5 \\
\text { years after implementation. }\end{array}$ \\
\hline Statistics & $\begin{array}{l}\text { Descriptive } \\
\text { statistics, } \\
\text { power } \\
\text { calculations, } \\
\text { weighted } \\
\text { Kappa- } \\
\text { coefficient, } \\
\text { Bland-Altman- } \\
\text { plot. }\end{array}$ & $\begin{array}{l}\text { Descriptive } \\
\text { statistics, ANOVA } \\
\text { (Bonferroni } \\
\text { adjusted), Chi- } \\
\text { square, logistic } \\
\text { regression, } \\
\text { sensitivity/specifici } \\
\text { ty-calculations. }\end{array}$ & $\begin{array}{l}\text { Descriptive } \\
\text { statistics, Chi- } \\
\text { square-test, binary } \\
\text { logistic regression. }\end{array}$ & $\begin{array}{l}\text { Descriptive statistics, Chi- } \\
\text { square-test. }\end{array}$ \\
\hline
\end{tabular}




\section{DATA SOURCES}

\section{Electronic medical records}

For studies I, II and IV, pregnancy and delivery data were collected from the electronic medical record (EMR) systems Cosmic CambioÒ and Obstetrix $^{\circledR}$. Information on pregnant women who attend the maternal antenatal clinics in the Region Östergötland is recorded in Obstetrix ${ }^{\circledR}$ (Cerner). This EMR system contains detailed, prospectively registered information for each pregnancy from the first visit until the mother and infant are discharged from the delivery hospital. These data include maternal reproductive, demographic and health data, prenatal maternal medical diagnoses, and pregnancy outcome for the mother and infant.

\section{Registers}

For study III, data from the Swedish Perineal Laceration Registry (PLR) was used. The PLR was started in 2014 in Sweden on the initiative of the Swedish Association of Local Authorities and Regions.

The PLR is a sub-section of the well-established Swedish National Quality Register of Gynaecological Surgery (GynOp)(82) that has operated since 1997. The PLR covers data from 36 of 45 delivery clinics and $85 \%$ of all births in Sweden. All participating delivery clinics report degree 3 and 4 lacerations to the PLR, while some units have chosen to also include women with a second-degree laceration. The aims are to facilitate identification and follow-up of women with complications, to give feedback from patients to the doctors and midwives repairing the lacerations, and to enable national comparisons and research into factors that influence patient-reported outcome measures (PROM). The PLR consists of medical data extracted from obstetric records on childbirth, as well as surgical data on suturing techniques of perineal lacerations. Selfreported data are collected by questionnaires at three time points: soon after childbirth (baseline), eight weeks postpartum, and approximately one year after childbirth. At each time point, the affected women respond to questions with pre-set response options, with unlimited space to add written responses.

Although the primary aim of PLR is to improve health care directly for women with larger perineal lacerations postpartum, it also makes it possible to study perineal lacerations on a larger scale and thereby improve knowledge on OASIS in the long run. 


\section{STUDY POPULATIONS AND STUDY DESIGNS}

\section{Study I}

Study population: The study population comprised forty women attending the gynaecological outpatient clinic. Apart from the ability to understand Swedish, there were no exclusion criteria nor selection regarding patient characteristics since the study objective was merely to evaluate the measurement technique. The mean age of the women was 47 years (range $18-83$ years) and their mean parity was 2 (range $0-5$ ).

As this was a methodological study concerning the learning curve and inter-observer agreement, three examiners with ultrasound experience of five, 15 and 21 years were chosen to perform the examinations.

Intervention: The exposure in study I was ultrasound measurement of the anovaginal distance (AVD) with a vaginal probe. The examinations were conducted during a regular gynaecological outpatient visit. The measurement was carried three times for each person, by two different examiners. The results of the measurements were documented in a protocol that was blinded to the other examiner.

The standardised transperineal ultrasound measurement of the AVD is carried out with a vaginal probe and the woman in the lithotomy position. The probe is placed at a right angle to the posterior vaginal distal wall and in a transversal scanning plane (figure 8 ). The probe is moved cranially from the distal anal canal to the mid-anal canal. The AVD in this thesis is measured and defined as the distance between the anal mucosa and the vaginal wall in the mid-anal canal and is mentioned in millimetres. In cases with internal sphincter injury, the distance between the inner edge of the anal mucosa and vaginal probe is measured.

Outcomes: Inter-observer agreement of transperineal ultrasound measurement of the AVD was the main outcome of study I. As there are no previous studies of this method, a difference of less than $5 \mathrm{~mm}$ between measurements was considered acceptable, based on clinical experience.

Three examiners were chosen based on their different levels of experience of vaginal ultrasonography, which were five, 15 and 21 years. Like most Swedish gynaecologists, they used vaginal ultrasonography in their daily 


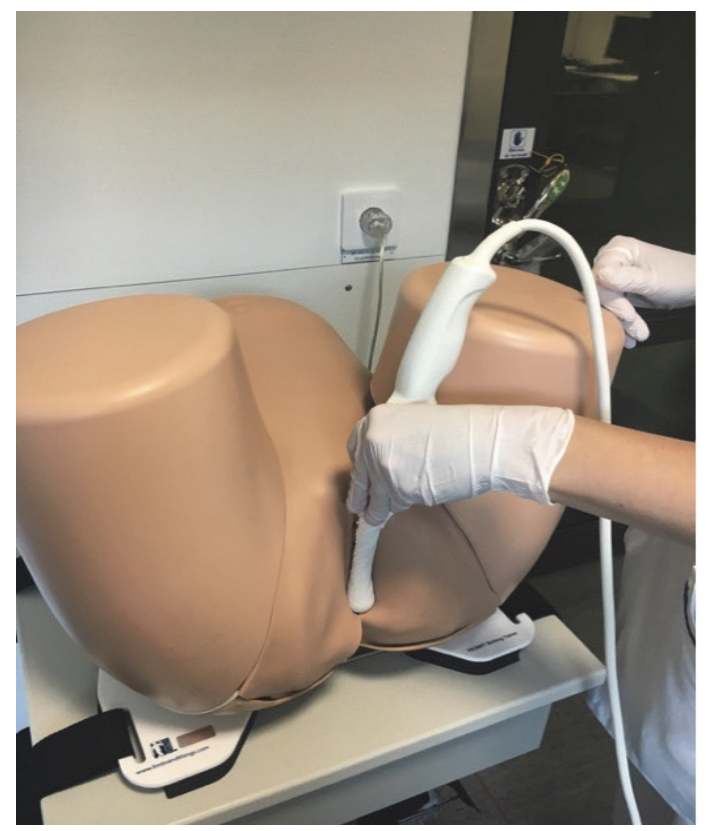

Figure 8. Measuring the anovaginal distance with a vaginal probe. Photo by Linda Hjertberg, M.D. and the author.

clinical practice to detect and measure internal genitalia distances. As the most experienced examiner was the inventor of the method, there was a learning period for the two new examiners. The introduction consisted of co-measuring the AVD and discussing the results openly, correcting details such as pressure, angle to the anal canal etc. By documenting this period of introduction, conclusions about the length of the learning period could be drawn.

As an additional observation, the inter-observer agreement, i.e. the difference between the measurements made by the individual examiner, was also examined, to exclude systematic confounders depending on individuals.

\section{Study II}

Study population: In study II, 150 women were included who had just had their first child and whose primary perineal examination postpartum raised a suspicion of a degree 2-3 laceration.

The target population was women who had their firstborn child through vaginal delivery at the delivery unit at the University Hospital in Linköping, Sweden, from October 2014 to January 2016. First- and fourth- 
degree perineal lacerations were not included since we assumed that anal sphincter injuries are rare (first-degree) or easily detected (fourth-degree) in those cases. Women who did not understand written or spoken Swedish or who had any prior perineal surgery or trauma were excluded.

In total, 1,399 women met the inclusion criteria. Of these, 292 women were asked about participation in the study and 150 were included after verbal informed consent had been received.

None of the women in the study population had undergone an episiotomy, which reflects the standard care at the delivery unit.

Ultimately, after the examination by the physician on duty, the women were diagnosed with lacerations of degree $2(n=121)$ or degree $3(n=29)$.

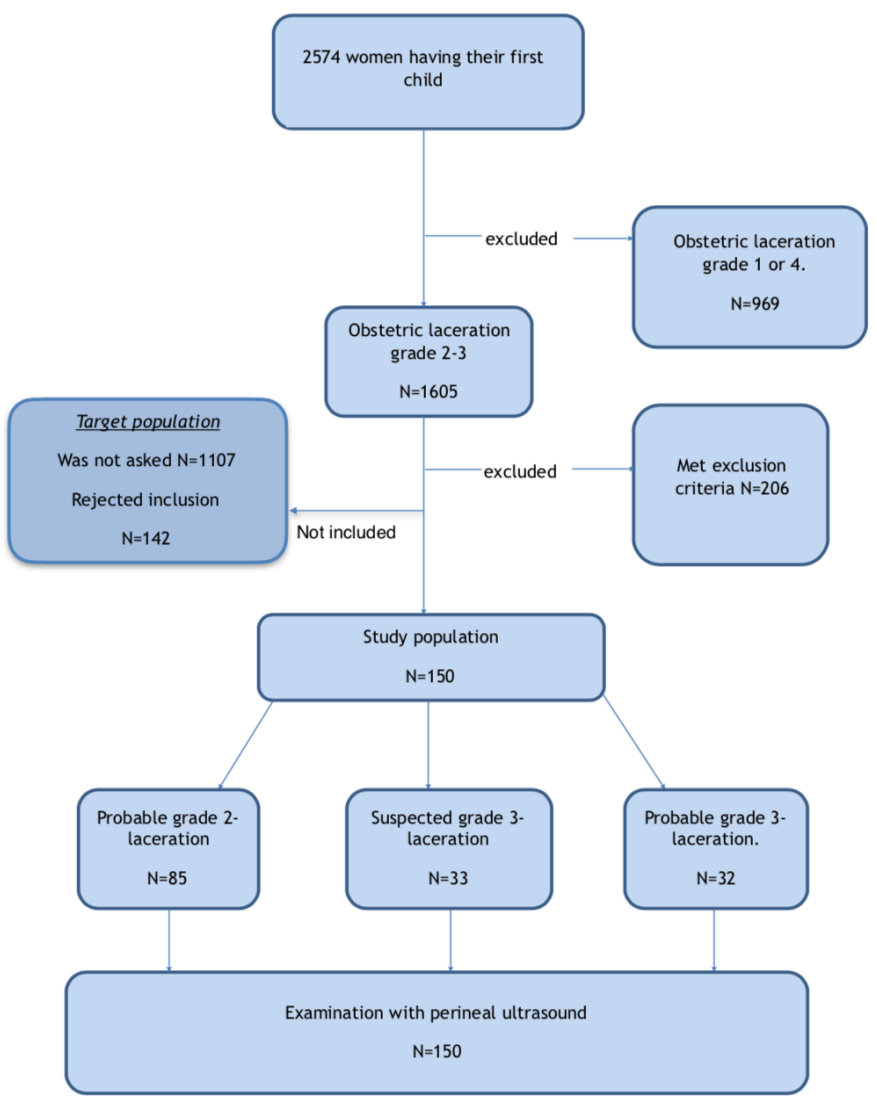

Figure 9. Flow chart of inclusion in study II 
Interventions: For the women who agreed to participate in the study, the midwives were instructed to decide on an initial diagnosis of the degree of the obstetric laceration after examination. Alternatives were "probable degree 2", "suspected degree 3" or "probable degree 3". The midwives' decisions were documented in the study protocol. The initial diagnosis of the lacerations according to the responsible midwife was probable degree 2 $(n=85)$, suspected degree $3(n=33)$ and probable degree $3(n=32)$.

The assessment of the bidigital palpation of the perineal thickness in millimetres was also documented in the study protocol. The midwives who first examined the perineal laceration made an estimation of the palpated perineal thickness and were asked to indicate their assessments in the closest 5 - mm intervals. The women were then examined by a specially educated physician, who was blinded to the midwife's initial diagnosis and palpated perineal thickness. The physician on call performed a standardised examination with transperineal ultrasound, measuring the AVD, and documented the result in the medical record. The final diagnosis of the perineal laceration was established by the physician on call according to standard procedure, inspection and palpation, but with the results of the ultrasound examinations available.

The laceration was repaired according to the clinic's local guidelines.

Outcomes: The primary outcome of study II was to determine whether there was an association between the AVD measured with transperineal ultrasound after delivery and diagnosed external anal sphincter injury.

A secondary outcome was to assess whether the midwives' initial bidigital examination of the perineum was in agreement with the measurement of the AVD with transperineal ultrasound carried out by the physician on call.

\section{Study III}

Study population: Study III is a cohort study that included all primiparous women with an anal sphincter injury registered in the PLR between January 2014 and September 2018. The study population was restricted to primiparous women in order to avoid the influence of previous deliveries on the pelvic floor anatomy. Among all the 6,000 primiparous women with a third- or fourth-degree perineal laceration, 3,333 had available information in the registry on the status of the IAS, and in 1,097 
women the IAS was injured. Women with no available data on the internal anal sphincter status or whose status in the PLR was not known were excluded from study III.

Exposures: The exposures of study III were maternal and obstetric characteristics known as risk factors or factors believed to be of importance for OASIS and available in the PLR data. Maternal characteristics chosen were age, body mass index (BMI), dyspareunia or genital discomfort before pregnancy, presence of inflammatory bowel disease (Crohn's disease or ulcerative colitis) or diabetes mellitus. BMI was calculated based on the maternal weight and height measurements provided at the first antenatal visit for the majority of the study patients. The other parameters were extracted from the answers of the self-reported questionnaire given to participating women the day after childbirth and included in the PLR baseline data.

The obstetric characteristics were induction of labour, analgesia during delivery, time of pushing, foetal presentation (crown, occiput posterior, breech or other), instrumental delivery (vacuum extraction or forceps), episiotomy, whether the infant was born with an arm beside the head, and birth weight.

The analgesic methods chosen were the clinically most common in the Swedish context, infiltration, pudendal block, paracervical block, spinal block and epidural block.

Concerning time of pushing, the study population was divided into three categories: less than or equal to 30 minutes, 31-60 minutes and 61 minutes or more, with less than 30 minutes as the category of reference.

The birth weight is a known risk factor for OASIS. In this population, birth weight was differentiated in less than or equal to 3,000g, 3,001-4,000g and more than 4,000 grams. The smallest children were used for reference. When studying diagnostic methods in perineal lacerations, available data in the PLR include the palpable perineal thickness and the use of ultrasound for evaluating the perineum. The outcome of the diagnostic method of bidigital palpation with one finger in the anal canal and the other in the deepest part of the vaginal laceration to determine the shortest the distance between the fingers, i.e. the perineal palpated thickness, is formalised in the PLR. The distance was classified into three groups (less than $10 \mathrm{~mm}, 10-20$ $\mathrm{mm}$ and more than $20 \mathrm{~mm}$ ). 
Outcomes: Injury of the internal anal sphincter was defined as the outcome in study III, compared to an isolated external anal sphincter injury.

\section{Study IV}

\section{Study population - setting}

The components of the DADEL concept was introduced in October 2014 at the delivery unit at the University Hospital in Linköping in Sweden, a tertiary referral delivery unit with around 3,000 deliveries annually. The staff, consisting of approximately 50 midwives and 20 physicians, share the work at the maternity ward. As the study had the intention of investigating the adoption of a new method, the setting consisted of the context at the maternity ward, including the staff, the personal characteristics, the formal and informal leader structures, the willingness to adopt new methods etc.

\section{Exposures}

When introducing the structured postpartum examination of perineal lacerations with the core components of quantitative bidigital palpation and transperineal ultrasound, a range of strategies concerning information on various levels at the clinic, education, and continuous feedback were executed. To reach adoption, strategies on individual level (83), collective (team/clinic) (84) and structural (policy) levels were executed. Efforts were made to reach as many of the staff as possible, even during night time.

\section{Outcomes}

In order to compare the use of concept core components of quantitative bidigital palpation and transperineal ultrasound immediately postpartum between the phases of implementation, medical record reviews were carried out covering three time intervals; when the implementation planning was set in March-April 2014 (baseline data), directly after the active phase March-April 2016 (post-implementation) and five years after the active implementation phase March-April 2019 (sustainability data). The baseline and post-implementation data were supposed to be used to study the impact of the active implementation strategies. The postimplementation data and the sustainability data were also examined as a measurement of the maintenance and sustainability of the concept use. 


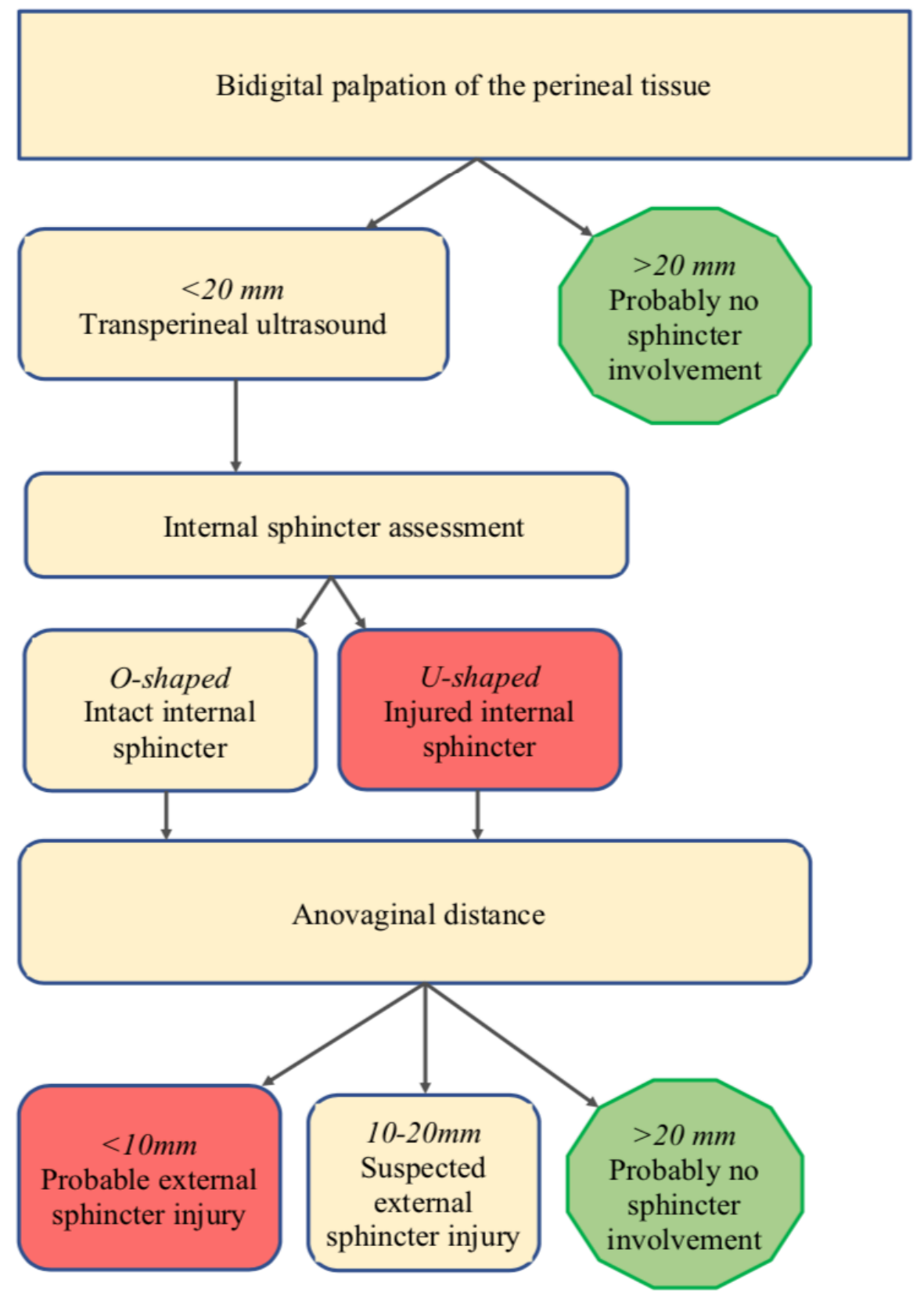

Figure 10. The Diagnostics After Delivery (DADEL)- concept. 


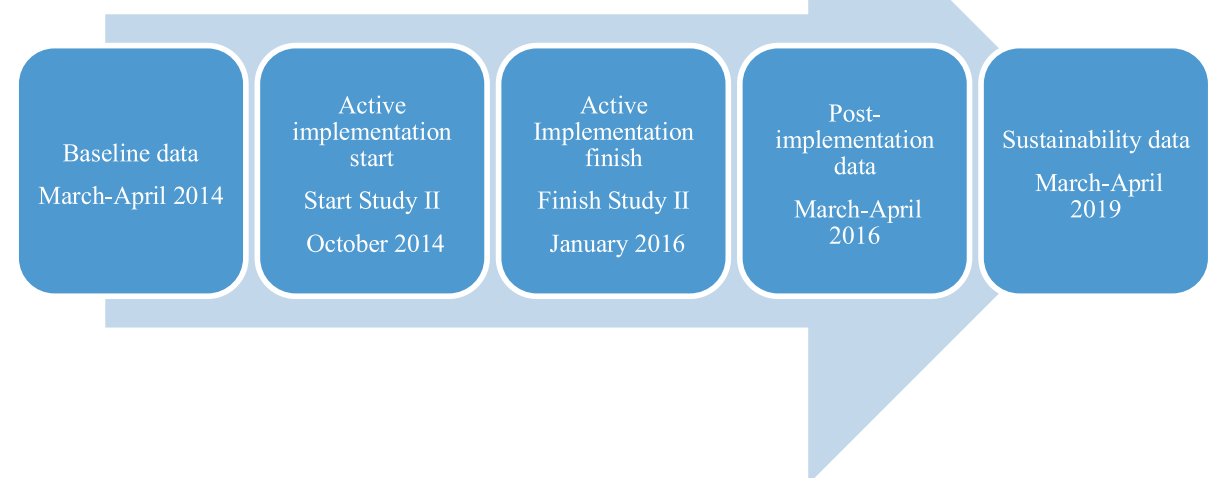

Figure 11. Timeline for active implementation and data collection in study IV.

\section{STATISTICS}

\section{Descriptive statistics}

In studies I-III the mean and standard deviations (SD) were presented for continuous variables and numbers and percentages for categorical variables. One-way analyses of variance (ANOVA) were conducted to compare descriptive, continuous data between groups and Chi-square tests were conducted for descriptive categorical data. A p-value less than 0.05 was considered as statistically significant.

In study I a sample size calculation was performed based on data from a pilot study of five measurements from two examiners. With a power of $80 \%$ and a two-sided significance level of alpha $=0.05$ and the accepted difference of $5 \mathrm{~mm}$ between examiners, 40 women were needed and were recruited for the study.

In study II, a large proportion of the target population was not asked about participation in the study. Therefore, a calculation of background characteristics between the study population and the target population, defined as all women that it was possible to recruit for the study, was made in order to investigate inclusion bias. Epidemiological parameters available were age, BMI, gestational week, smoking in early pregnancy and living with a partner. 
There was a statistically significant difference in gestational week between the women included in the study (39.96 w) and the target population (39.50 w). However, the difference was considered clinically not relevant and no other inclusion bias was found.

\section{Analyses of outcomes}

Study I. The mean AVD based on the three measurements obtained by each examiner were paired for every patient. Inter-observer agreement was assessed using the weighted kappa coefficient. Weighted Kappa was used in order to weight the range of agreement; when using a continuous parameter as difference of less than 5 millimetres as a total agreement, but not wanting a difference slightly above $5 \mathrm{~mm}$ to count as a total disagreement.

With an accepted difference of $\leq 5 \mathrm{~mm}$ inter-observer variation, the weighted kappa coefficient was $0.87(\mathrm{p} \leq 0.001)$ with an agreement of $92.5 \%$, classified as almost perfect agreement. Variation in the measurements was not significantly influenced by the actual length of the AVD, which is shown in the Bland-Altman plot.

The intraobserver variability ranged from 0.1 to $3.9 \mathrm{~mm}$ and there was no difference in variability in relation to years of experience. Examining systematic errors comparing mean measurements and SD, there were no significant differences between individual examiners regardless of their experience with the use of vaginal ultrasonography in basic gynaecological clinical care.

The statistical analysis in this study was performed using Stata v. 13.1 (Statacorp LP, College Station, TX).

Study II. ANOVA statistical methods were used in calculations concerning AVD and external sphincter injury and concerning the AVD and initial palpation thickness. As a post hoc test, Bonferroni was used. Logistic regression analysis was used in calculating the relation of AVD as a continuous variable and external sphincter injury. A p-value $<0.05$ was considered statistically significant.

Sensitivity, specificity and predictive values for AVD were calculated using cross tabulation, as shown in the Findings section below.

In study III, the maternal variables age, BMI, dyspareunia scale, genital discomfort before pregnancy, inflammatory bowel disease and diabetes, 
were known risk factors for extensive perineal lacerations or known to be of special importance. However, there were no significant differences in maternal characteristics between groups. The obstetric variables were entered in binary logistic regression analyses. Reference categories for the analyses were chosen as follows: spontaneous delivery start, no episiotomy, palpable thickness $>20 \mathrm{~mm}$, perineal laceration degree 3 . The parameter of time of pushing was categorised into less than or equal to 30 minutes, 31-60 minutes and more than 60 minutes, with the shortest pushing time as the reference category. The parameter of birth weight was consistently categorised into less than or equal to $3,000 \mathrm{~g}, 3,001-4,000 \mathrm{~g}$ and more than $4,000 \mathrm{~g}$, with the lightest birth weight as the reference. None of these parameters showed any statistically significant differences in any categories.

Odds ratios (OR) were calculated with $95 \%$ confidence intervals (CI). All analyses were two-sided.

In study IV, comparisons of proportion of use of the diagnostic methods were made between the implementation phases using Chi-square tests.

In study II-IV, statistical analysis was undertaken with SPSS Statistics, version 24 (IBM Inc, Armonk, NY, USA). 


\section{ETHICAL APPROVAL AND CONSIDERATIONS}

The studies in this thesis were approved by the Regional Ethical Review board in Linköping (Study I; Dnr 2013/202-31, study II; Dnr 2014/248-31, study III; Dnr 2016/144-31 and study IV Dnr 2014/247-31).

In studies I and II, all participating women received written and verbal information and gave informed consent. This was documented in the individual digital medical record. In study II, the information about the ongoing studies was given at the antenatal clinic, as the possibility to take in the information and give an informed consent was considered limited immediately after delivery. The final consent and inclusion happened after delivery. The sustainability data in study IV was according to ethical approval of clinical monitoring.

In study III, the non-identifiable data drawn from the PLR was obtained without personal informed consent specifically for this study. Research with data from large data registers does not require personal informed consent. The Personal Data Act (1998) aims to prevent the violation of personal integrity in the processing of personal data. Before handling of sensitive personal data, such as health data, can take place, permission from a regional ethical review board is required. Inclusion of data in the PLR requires consent from the patients and participation of the register is voluntary before leaving the information and according to the General Data Protection Regulation GDPR. After ethical approval was obtained and applications made to registered holders of the PLR, data for this study were retrieved unidentified. 


\section{RESULTS}

\section{Findings of study I}

The main finding in study I was that the inter-observer agreement in performing transperineal ultrasound with a vaginal probe for measuring AVD showed almost perfect agreement when measuring women without any perineal symptoms or discomfort in an outpatient clinic. The mean difference in the AVD measurements was $1.8 \mathrm{~mm}(95 \%$ CI $1.13-2.45 \mathrm{~mm}$, $99 \%$ CI $0.91-2.68 \mathrm{~mm}$ ). With an accepted difference of $\leq 5 \mathrm{~mm}$ in interobserver variation, the weighted kappa coefficient was $0.87(\mathrm{p} \leq 0.001)$ with an agreement of $92.5 \%$. Variation in the measurements was not significantly influenced by the length of the AVD. Inter-observer variation is shown in figure 12 .

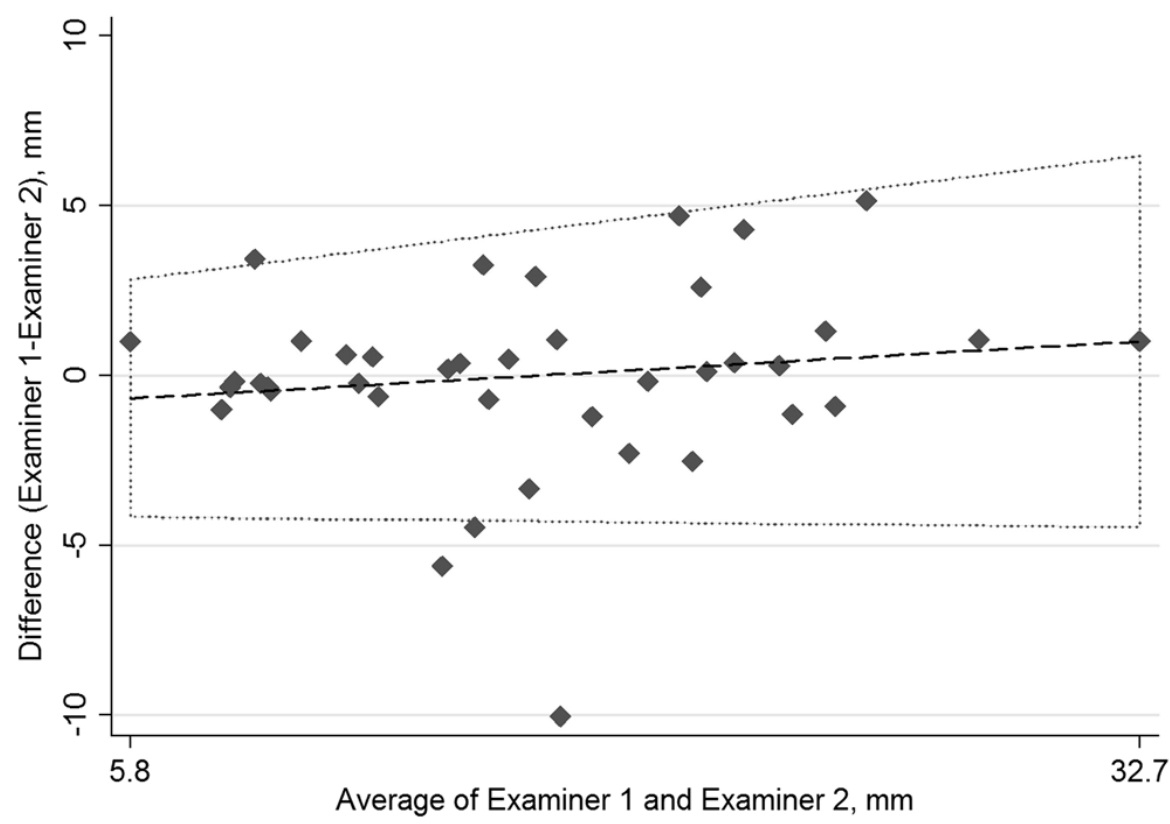

Figure 12. Bland-Altman plot of interobserver differences in measured anovaginal distance.

A new examiner achieved proficiency after co-measuring five patients, each three times, describing a short learning curve for an examiner with previous experience of vaginal ultrasound examinations. 
The intra-observer variability ranged from 0.1 to $3.9 \mathrm{~mm}$ and there was no difference in variability in relation to years of experience. When examining systematic errors comparing mean measurements and standard deviations, there were no significant differences between individual examiners regardless of their experience with the use of vaginal ultrasonography in basic gynaecological clinical care (data not shown).

The AVD in this totally unselected population was between 5.3-33.2 mm, mean $16.6 \mathrm{~mm}$.

\section{Findings of study II}

The main result in this prospective observational study of 150 primiparous women immediately after childbirth was that women with an ultimately confirmed diagnosis of external sphincter injury had a shorter AVD compared with women with a perineal laceration without external sphincter injury. The palpatory perineal thickness estimated by the midwife was associated with the measurement of the transperineal ultrasound of the AVD.

A final diagnosis of external sphincter injury was associated with a shorter ultrasound- measured AVD. In the group ultimately diagnosed as having an external sphincter laceration, the mean AVD was $11.6 \mathrm{~mm}$ (95\% CI 9.313.8). In the group ultimately diagnosed with a second-degree laceration, the mean AVD was $17.8 \mathrm{~mm}$ (95\% CI 16.9-18.7); thus, the mean AVD difference between the second- and third-degree lacerations was $6.2 \mathrm{~mm}$ (95\% CI 4.1-8.4, $\mathrm{p}<0.001)$. When assessed as a continuous variable, AVD was also inversely related to an external sphincter laceration $(\mathrm{p}<$ 0.001).

Retrospectively, based on knowledge from the present study of potential positive/negative test results, we calculated the sensitivity, specificity and predictive value. 


\begin{tabular}{|c|l|l|l|}
\hline & $\begin{array}{c}\text { External sphincter } \\
\text { injury }\end{array}$ & $\begin{array}{c}\text { No external } \\
\text { sphincter injury }\end{array}$ & \multicolumn{1}{|c|}{ Totally } \\
\hline AVD $<=\mathbf{2 0 m m}$ & 28 & 91 & 119 \\
\hline AVD $>\mathbf{2 0 m m}$ & 1 & 30 & 31 \\
\hline Totally & 29 & 121 & \\
\hline
\end{tabular}

Sensitivity: $28 /(28+1)$

Specificity: 30/ $(30+91)$

Positive predictive value: $28 /(28+91)$

Negative predictive value: $31 /(30+1)$

Using an AVD cut-off of $>20 \mathrm{~mm}$, the sensitivity for sphincter injury was $96 \%$ and the specificity was $25 \%$. The positive predictive value was 0.23 , and the negative predictive value was 0.97 .

The measured AVD was shorter in the midwife-assessed third-degree lacerations than in the second-degree lacerations. The mean AVD in the group with probable second-degree laceration $(\mathrm{n}=85)$ was $18.8 \mathrm{~mm}(95 \%$ CI 17.8-19.8, SD $4.5 \mathrm{~mm})$, in suspected third-degree laceration $(\mathrm{n}=33)$ it was $15.7 \mathrm{~mm}(95 \% \mathrm{CI} 13.7-17.7$, SD $5.6 \mathrm{~mm})$, and in probable thirddegree laceration $(\mathrm{n}=32)$ it was $11.8 \mathrm{~mm}(95 \%$ CI 9.7- 13.9, SD $5.8 \mathrm{~mm})$ $(\mathrm{p}<0.001)$.

\begin{tabular}{|c|c|c|c|c|}
\hline \multicolumn{2}{|c|}{} & $\begin{array}{c}\text { AVD } \\
\text { Mean Difference } \\
(\mathbf{m m})\end{array}$ & $\begin{array}{c}\text { CI } \\
(\mathbf{9 5} \%)\end{array}$ & p-value \\
\hline $\begin{array}{c}\text { Probable } \\
\text { degree 2 laceration }\end{array}$ & $\begin{array}{c}\text { Suspected } \\
\text { degree 3 laceration }\end{array}$ & 3.1 & $0.6-5.6$ & 0.010 \\
\hline $\begin{array}{c}\text { Probable } \\
\text { degree 2 laceration }\end{array}$ & $\begin{array}{c}\text { Probable } \\
\text { degree 3 laceration }\end{array}$ & 7.0 & $4.4-9.5$ & $<0.001$ \\
\hline $\begin{array}{c}\text { Suspected } \\
\text { degree 3 laceration }\end{array}$ & $\begin{array}{c}\text { Probable } \\
\text { degree 3 laceration }\end{array}$ & 3.9 & $0.8-6.9$ & 0.008 \\
\hline
\end{tabular}

Table 4. Mean anovaginal distance between the midwife-assessed palpation groups. AVD - Anovaginal Distance. CI - Confidence Interval. 
Comparing the mean anovaginal distance between probable second-degree lacerations and suspected third-degree lacerations, the differences are shown in table 4.

The bidigital palpation was classified in five subclasses, palpation thickness 0-5 mm, 6-10 mm, 11-15 mm, 16-20 mm, and $21 \mathrm{~mm}$ and above. The AVD differed significantly in the palpation subgroups, as seen in figure 13.

There was no statistical significance between inclusion in the study daytime or nightshift $(\mathrm{p}=0.84)$.

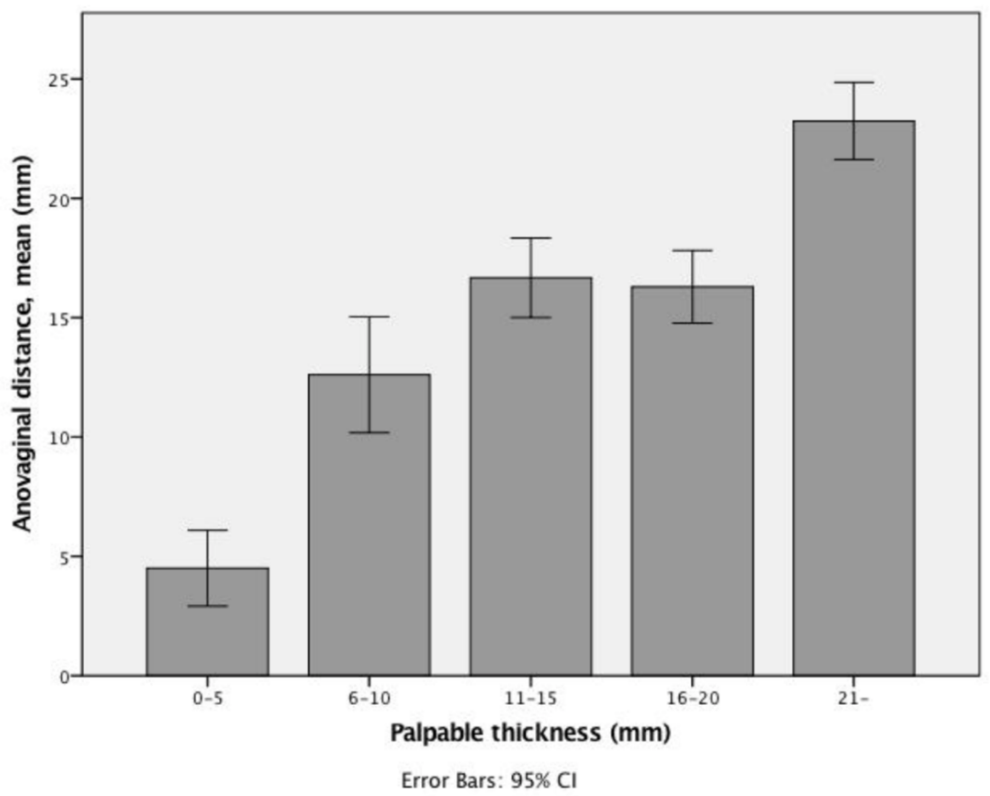

Figure 13. The palpated perineal thickness and corresponding anovaginal distance (AVD) immediately after delivery. 


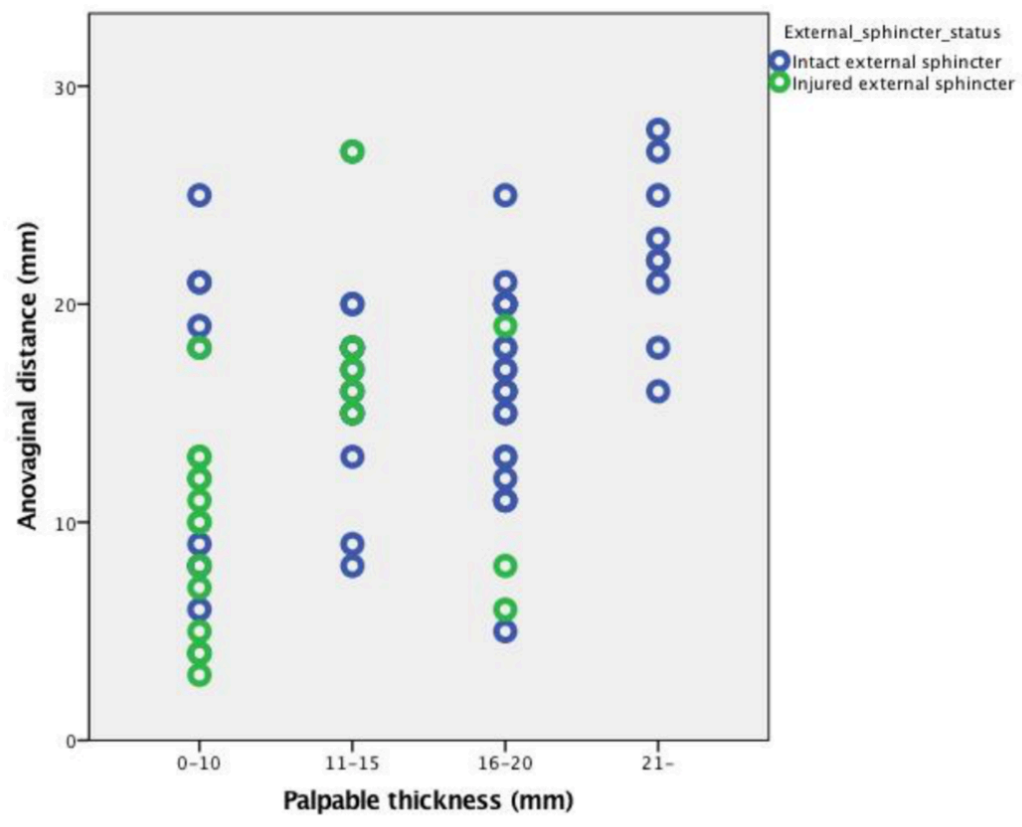

Figure 14. The palpated perineal thickness and corresponding anovaginal distance (AVD) immediately after delivery considering the ultimately diagnosed external sphincter status.

\section{Findings of study III}

In this study, a wide range of maternal and obstetric parameters were studied considering internal sphincter injury. The main findings were that in 33\% (N=1097/3333) of primiparous women with an EAS injury, an IAS injury was diagnosed immediately after delivery. When the infant was born with a hand or arm beside the head, there was an increased risk for IAS injury. Risk factors associated with EAS injury, including birth weight, instrumental delivery and occiput posterior presentation, could not be confirmed as independent additional risk factors for IAS injury. Concerning diagnostic methods in the immediate postpartum period, a perineal palpatory thickness of less than $10 \mathrm{~mm}$ was significantly associated with an IAS injury when compared with a palpatory thickness of $20 \mathrm{~mm}$ or more. 
However, one striking finding related to this was the rate of documented status of the internal anal sphincter. Of all 11,459 women registered in the PLR during 2014-2018 (both primiparous and multiparous), there were $35.7 \%$ degree 2 -lacerations, $59.1 \%$ degree 3 lacerations and 5.3\% degree 4lacerations. The IAS was recorded as intact in $40.3 \%$ and injured in $11.5 \%$ of the registered lacerations. In $4.9 \%$, the IAS was recorded as not examined and in $43.4 \%$ the information was missing. Whether these findings are due to registration errors or reflect an actual low examination rate of the IAS status postpartum is unknown.

The bidigital palpation rate in the total population of the PLR during this time interval was "less than $1 \mathrm{~cm}$ " $15.8 \%$, "between $1-2 \mathrm{~cm}$ " $15.8 \%$ and "more than $2 \mathrm{~cm}$ " $7.9 \%$. That leaves $60.4 \%$ without documented information about the palpable perineal height in this material. The rate of ultrasound help in diagnostics was 75/11459 divided among 13 hospitals in Sweden, which suggests that the ultrasound is not a frequent diagnostic method for perineal lacerations.

\section{Findings of study IV}

Five years after the introduction of the DADEL concept and three years after the last structured implementation effort, the quantitative bidigital palpation was in clinical use to a significantly higher extent than before the implementation. The use of transperineal ultrasound during the same time period showed no significant change.

The time of measuring intervals were made to study the baseline usage of the methods of quantitative bidigital palpation and transperineal ultrasound, how the methods were used directly after the study, and whether the personnel continued using the palpation and ultrasound in daily practice five years after the implementation, the latter being called sustainability. As a complement, a measurement was also carried out mid-implementation. The result of this measurement is included in figure 15 and 16, and shows, as expected, increased usage of the methods during active implementation compared to baseline. 


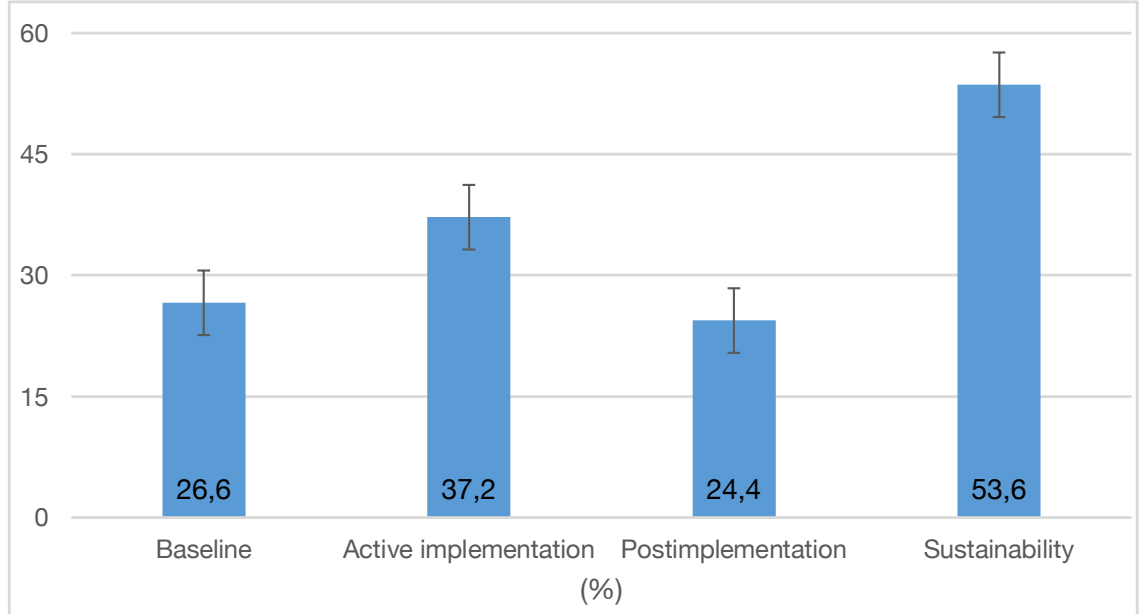

Figure 15. Proportion of quantitative bidigital palpation of primiparous women with perineal laceration grade 2-3. CI 95\%.

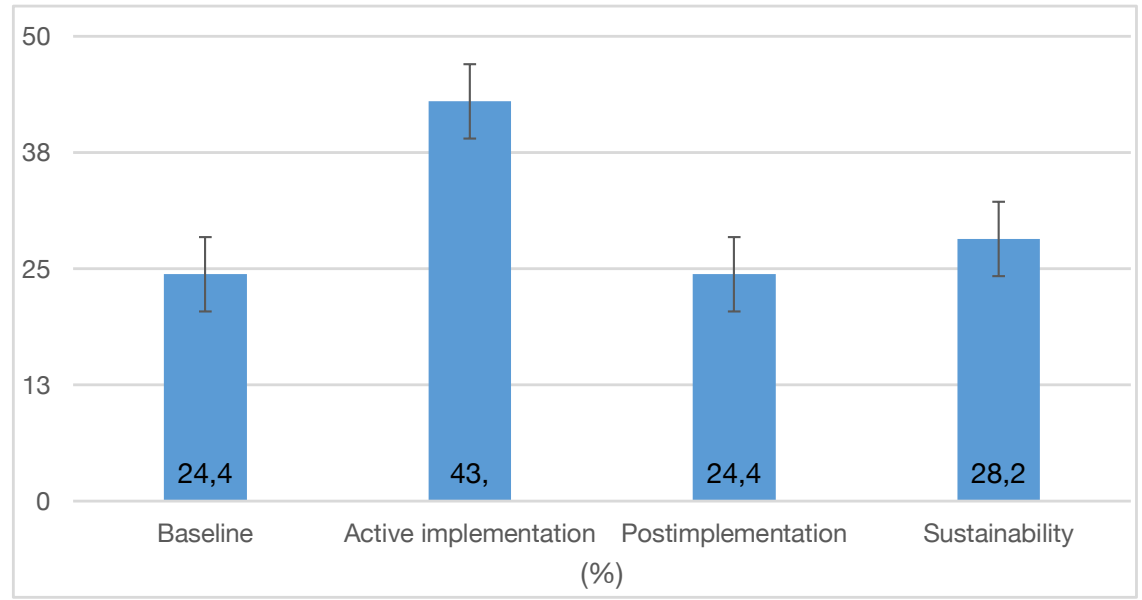

Figure 16. Proportion of transperineal ultrasound in primiparous women with perineal laceration grade 2-3. CI 95\%. 


\section{DISCUSSION}

\section{METHODOLOGICAL DISCUSSION}

In this thesis, four different study types have been used, each with methodological issues to be considered.

When planning for a study, judgements have to be made considering the probability of making a type I- or type II-error. A Type I error is to reject a null hypothesis that is true, whereas a type II- error is not to reject a null hypothesis that is false $(85,86)$.

In this thesis, a p-value of 0.05 was set as the significance level in all four studies, describing the risk of a type I error throughout. However, this does not imply the level of clinical relevance or clinical importance. In studies with large cohorts, statistical significance can be reached with small actual differences.

Study I is a methodological study of inter-observer agreement and the learning curve in a diagnostic method, not in clinical practice. Planning for this study included an estimation of power and of how many examinations needed to be done to make fair calculations of the result, as opposed to not include too many study persons as an ethical consideration.

The power of a study calculates the probability of not making a type IIerror. This means an estimation of sample size has to be made. In this case, having no similar studies to compare with, a power of $80 \%$ was chosen and a clinically relevant difference between examiners was estimated to be 5 millimetres in every examination. This means a $(1-0.8=0.2) 20 \%$ risk of a type II-error (85). With these conditions, it was calculated that 40 study persons needed to be included.

In study II, which was a prospective observational study method, there were other methodological considerations.

The method of transperineal ultrasound for measuring AVD had been studied in an out-clinic patient population without perineal symptoms in study I. Translating the method to a maternity ward population immediately after childbirth may reduce generalizability. Since there was an ethical consideration in revalidating the method in the postpartum population with an additional examiner, besides the responsible midwife 
and the physician on call, the decision was to use the method in the study as the examination was not considered to be technically complicated. Diagnostic testing and evaluation studies are considered to have an observational rather than an interventional study design (87). In a diagnostic testing study, the comparison is usually with the golden standard method, using a cross-sectional study of both healthy and diseased study persons in order to study both the sensitivity and the specificity of the studied method.

In this study, the golden standard was considered to be standard procedure, i.e. inspection and palpation of the perineal laceration, and the new method of transperineal ultrasound was supposed to be compared to that. An alternative would have been to use the endoanal ultrasound as the golden standard, as it is widely used in women with perineal pain or anal incontinence, often in a colorectal context. However, as it is not used in clinical practice at any maternity ward known to us, the standard examination was a more logical comparison in this setting.

That means that after inspection and palpation of the tissues, the initial examiner, the midwife, was supposed to document the quantitative bidigital measurement in $5 \mathrm{~mm}$ intervals and estimate the degree of perineal laceration. Following this, a transperineal ultrasound complemented the examination and the final diagnosis was made before suturing. However, an unthought-of intricacy occurred. As the intention of the study was known to all, when studying the medical journal there was a clear intention by the primary examiner not to underestimate the degree of the laceration and thereby cause the initial "standard" examination to be re-diagnosed by the second examiner using the ultrasound. Because of this, even when the bidigital measurement was high, the initial diagnosing was carried out with caution. This was a natural psychological effect we had not foreseen and could possibly lead to underestimation of the diagnostic support of the transperineal ultrasound.

In diagnostic evaluation studies, evaluations of diagnostic test results should be blinded to the case status of the participant. Such an instruction was included in the study information and meant that the results of the first estimation were supposed to be blinded to the next examiner and to the woman. However, we were not able to verify if this happened in every case of clinical practice. 
Possibly the largest methodological intricacy in study II concerns how the results of the studied diagnostic methods influenced the final diagnosis. The palpation result was blinded to the physician on call who made the final diagnosis, but the result of the ultrasound was not, as the physician on call performed the ultrasound. At the time, no information about the normal values of the AVD was available, but an examiner using the technique frequently would inevitably built her own reference bank. Optimally, the examiner and the person responsible for the final diagnosis should have been separated, but that was not practically feasible. This might have increased the probability of a degree 3-laceration in the case of a low measurement of AVD. However, it is not likely that the diagnosis of a degree 3 or 4 laceration based on traditional methods would have been withdrawn because of a high measurement of AVD.

Another kind of observational study design is used in study III, the retrospective cohort study, using a registry to evaluate the association between any given exposure and a specific outcome. In this study, the Swedish National PLR was used. The large size of the cohort allowed us to restrict our data to only include primiparous women, to get a cohort without errors due to earlier lacerations. However, when extracting data from a registry, a major disadvantage is that the data is limited to the information put into the registry. In the case of the PLR, we extracted information from the very start of the registry 2014, aware of the problems with collecting data when introducing new routines. Therefore, the data in the PLR is not judged to be complete, but there is no reason to suspect incorrect data in the available registry.

Observational cohort studies are common when studying obstetrics, as randomisation is impossible or unethical (88). The study design is affected by systematic and random errors, which compromises the internal validity. Due to the cohort size, the risk of random errors is minimised. However, there are three kinds of systematic errors; selection bias, misclassification bias and confounding bias.

Selection bias occurs when the unexposed group in a study differs from the exposed in other ways than the exposure. The unexposed group is supposed to act as an counteract to the exposed group, differing in no other way from the exposed group than the exposure. The unexposed group should thereby mirror the exposed group had they not been exposed. 
In our study, the outcome was combined EAS and IAS injury. Baseline maternal characteristics were studied, chosen by known influencing factors for extensive perineal lacerations, showing no differences between when the outcome was negative (i.e. isolated EAS injury) or positive (combined EAS and IAS injury).

Misclassification bias occurs when information is recorded or interpreted inaccurately and thereby might lead to misclassification. The risk of misclassification bias depends on the distinctness of the endpoint chosen. If the endpoint is unconditionally binary, such as life/death, the risk of misclassification is very small. If the chosen endpoint is dependent on interpretation, the risk is higher. For example, in our case, women who had a vacuum extraction may be more thoroughly examined than women giving birth non-instrumentally, might cause misclassification bias. In this case with a register, there is no opportunity to control these conditions, but it is important to recognise that the risk exists.

Confounding bias is when there is an outside factor that affects both the exposure and the confounder, which is not adjusted for. These factors might be hard to identify by calculation and they often have to be known by their causal relation to exposure and outcome in order to be adjusted for. In our study, we did not identify any confounding factors.

Generalizability refers to the extent to which findings and interpretations of a given study can be applied to other populations and settings with similar characteristics, also known as external validity. As study III collected data on all available external and internal anal sphincter injuries in Sweden 2014-2018, the generalisability is considered high in similar settings. In other countries, with different traditions, maternal characteristics and access to health care, the findings cannot be considered generalisable.

In study IV, a descriptive study design was chosen, combined with a quantitative follow-up measurement of outcome (use of the DADEL concept). When introducing a new method in clinical practice, much consideration should be given to the planning phase concerning time lines, communication strategies, identifying key persons, documentation etc. (89). How the evaluation of the outcome is to be carried out should preferably be planned before the introduction phase. The advantage of thorough planning is obvious, with as few changes and individual 
interpretations as possible. The drawbacks are that it is time- and resourceconsuming.

During the implementation of the DADEL concept, the individuals responsible for the study were also registering the implementation strategies. The possible risk of influencing the implementation when responsible persons are present is obvious and to a certain degree desirable during the implementation, but to a lesser degree in the sustainability phase. This study can be considered to be a sample of possible implementation strategies in a maternity ward and can facilitate tailoring of the strategy plan when implementing the DADEL concept in other hospitals.

\section{DISCUSSION OF FINDINGS IN STUDIES I-IV AND CLINICAL IMPLICATIONS}

When we started planning this thesis, our main hypothesis was that the methods we use for diagnosing perineal lacerations after childbirth were not structured, not objective, and thus not equal.

By structuring the diagnostic flow into a systematic way of examining and documenting the findings, the clinical decisions made in the immediate assessment of occult sphincter injuries could be more solid and the documented findings would be easier to understand and compare in possible complication treatment after an anal sphincter injury.

As the method of bidigital palpation and transperineal ultrasound had been used at the clinic primarily in assessments of the pelvic floor in a more gynaecological outpatient setting, there was a need to study the use in diagnostics of obstetric lacerations immediately after childbirth. The method had not previously been evaluated scientifically. Initially, there was a need to validate the ultrasound method, the interobserver agreement and the learning process with a new examiner who was accustomed to the use of ultrasound with vaginal probes. This study is simple and straight-forward in its intentions, but there was a strategic problem in studying the validity of a method not used in any structured clinical implication at the time, and an educational complexity in describing how the method was supposed to be used without research supporting it. 
As a continuation from the study of education and validation of the transperineal ultrasound of AVD, the intention was to start using bidigital palpation and transperineal ultrasound as diagnostic tools in a clinical setting at the maternity ward, and to use them immediately after childbirth, before primary suturing. In research, only one study in this setting could be found, in that case using endoanal ultrasound (49).

In study II, the major result was that women with a diagnosis of external sphincter injury had a shorter AVD compared to women with a perineal laceration without external sphincter injury. The palpatory perineal thickness estimated by the midwife was in agreement with the transperineal ultrasound measurement of AVD.

This could indicate that a quantitative bidigital palpation could be used in isolation without decreasing diagnostic security. However, we suggest using a complement of the AVD in diagnostics of obstetric perineal lacerations. This should be done in order to confirm the palpable findings in those cases where palpation is complicated and to identify the status of the internal anal sphincter as a diagnostic addition, even though this was not an aim of study II.

Many women with all inclusion- and no exclusion criteria for study II were not documented whether they were asked about inclusion in the study. The reason for register not asked could hypothetically be a registration failure, when the women got the question but declined inclusion. Another condition could be a staff selection of asking, dependent on the subjective assessment of the responsible midwife or physician on call or the workload at the ward not allowing the inclusion process (90). After drop-out analysis, the women included did not differ in basic maternal characteristics or time of the day/night from the women not included in the study, and therefore the drop-out rate should not influence the results of the study. The difference in gestational length noticed with slightly higher gestational age in the participating group might be due to not asking women who very recently had a premature childbirth to participate in a research study. The difference was considered statistically significant but not clinically relevant.

Study IV was introduced before study II, and took place, in part, parallel to this, by implementing strategies for imparting information and education. When introducing the education and clinical use of the DADEL 
concept in study IV as part of studying implementation strategies, the method was well accepted. During this time, the mass media paid great attention to occult anal sphincter injuries and the causes of long-term complications such as anal incontinence, perineal pain and dyspareunia. When introducing the PLR in 2014, the feedback from the women at follow-up questionnaires made individual motivation to improve diagnostics high. In the PLR, the responsible health staff get individual feedback from questionnaires the women answer at eight weeks and one year postpartum.

The health staff intentions when diagnosing and repairing an obstetric laceration are to facilitate uncomplicated healing with a sustainable result. When feedback indicates another outcome than the intended one, it can be a reminder to examine whether systemic, clinical or individual improvement is possible.

The invention of transperineal ultrasound with a vaginal probe had, as mentioned, been used at the study clinic earlier in other settings. When working out the use of ultrasound in diagnosing perineal lacerations postpartum in study III, the Linköping maternity ward conducted $47.2 \%$ of the ultrasounds in the PLR in 2014-2018. This might be a contributing explanation for the lack of an increasing proportion of ultrasound examinations in study IV, i.e. the method had already been partly implemented due to passive dissemination throughout the clinic. When introducing the pelvic floor education programme in 2017, recommending quantitative bidigital palpation, there was a distinct increase in the use of this method in primary examinations after childbirth at the clinic. It is possible that the staff responsible for the delivery were already familiar with the palpation method because of study II. To discover if this is true, a comparison of diagnostic laceration methods with another maternity ward would have been appropriate.

Study III is the first quantitative study of the PLR since the registry was introduced in 2014 and has the largest cohort of persons with IAS injury in a study to our knowledge. The diagnostic methods of internal anal sphincter injuries are not well studied, and to our knowledge, there are no previous studies on maternal or obstetric risk factors for IAS injury. To our knowledge, this is also the first study conducted on diagnostic methods used before primary suturing. 
The incidence of IAS injury varies in studies, and in most studies on OASIS, the IAS is not mentioned at all.

Ozyurt et al. (54) studied 201 primiparous women with transperineal ultrasound after delivery before hospital discharge. Seven women had an OASI and two had an IAS injury (28\%). In a study by Mahony (42), 500 women with a diagnosis of OASI were examined with endoanal ultrasound three months after childbirth. They showed a 38\% partial and $18 \%$ total thickness defect of the IAS. Roos et al. (43) showed that $8 \%$ of women with OASI had been diagnosed with an IAS injury at the time of the primary repair. In that study, $27 \%$ of the women had an IAS injury that was found with an endoanal ultrasound nine weeks after delivery but that had not been found in the delivery setting.

The different rates in these studies of persistent, undetected IAS injury probably reflect low awareness and diagnostic abilities in the primary settings.

However, regarding endosonic, often endoanal signs of sphincter defects and symptoms of anal incontinence, the relationship is not clear. A full thickness defect of the IAS seems to be highly predictive of faecal incontinence, whereas the importance of partial defects of the IAS and different signs of defects in the EAS is less clear $(35,41-43,49,50,53,63$, $66,68,91-98$ ).

A surprising finding in study III was that $28 \%$ of the registered degree IVlacerations defined the IAS as intact. According to ICD, a degree 4 laceration is defined as an injury of the perineum involving the anal sphincter complex (both the EAS and IAS) and anal epithelium.

There are various possible explanations for this finding. Some lacerations classified as a fourth-degree tear may in fact be an injury of the EAS. The misunderstanding may lie in differentiating between an injury of the anal epithelium above the dentate line (fourth-degree) and an injury of the anal skin up to the dentate line. This distinction in anatomy might not be known and has now been addressed and clarified in the education programme as a result of this study. A true fourth-degree laceration stretching above the dentate line with an intact IAS is anatomically unlikely. 


\section{CONCLUSIONS}

Based on the studies included in this thesis the following conclusions may be drawn:

- Transperineal ultrasound measurement of the anovaginal distance showed a short learning period for new examiners with previous experience in vaginal ultrasound examinations. (study I)

- Transperineal ultrasound measurement of the anovaginal distance had an almost perfect inter-observer agreement. The method described can be taught and reliably used in further research. (study I)

- A diagnosis of external sphincter injury is associated with a shorter ultrasound-measured AVD. (study II)

- The initial bidigital examination of the perineum is associated with the anovaginal distance measured with transperineal ultrasound. (study II)

- $33 \%$ of women with an external anal sphincter injury were diagnosed with an internal anal sphincter injury immediately postpartum. (study III)

- When the infant was born with a hand or arm beside the head, there was an increased risk for IAS injury. Risk factors associated with EAS injury, including birth weight, instrumental delivery and occiput posterior presentation, could not be confirmed as independent risk factors for IAS injury. (study III)

- Concerning diagnostic methods in the immediate postpartum period, a perineal palpatory thickness of less than $10 \mathrm{~mm}$ was significantly associated with an IAS injury when compared with a palpatory thickness of $20 \mathrm{~mm}$ or more. (study III)

- The range of implementation strategies used when establishing the diagnostics after delivery (DADEL)-concept for diagnosing obstetric 
perineal lacerations at a maternity ward were mainly divided into information, education and feedback strategies. (study IV)

- Five years after the introduction of the DADEL concept and three years after the last structured implementation effort, the quantitative bidigital palpation is in clinical use to a significantly higher extent than before the implementation. The use of transperineal ultrasound during the same time period showed no significant change. (study IV) 


\section{FUTURE PERSPECTIVES}

The number of internal anal sphincter injuries possible to find with transperineal ultrasound immediately after childbirth compared to standard care is not known. A study with transperineal ultrasound for diagnosing injuries of the IAS and measuring the prevalence of IAS during a longer period of time would be interesting.

A prospective study of the women diagnosed with IAS injury before primary suturing, and of their quality of life would be of interest. Previous studies suggest that an occult and undiagnosed IAS injury can cause considerable complications. It would be interesting to study whether this is preventable when the IAS is identified and repaired correctly.

When studying the bidigital palpation measurements and the anovaginal distances in the PLR, many measurements were very low according to the suggested DADEL concept, but the lacerations were still classified as degree 2. An interesting study would be to follow the women with a measurement of palpated perineal height or AVD less than for example 10 $\mathrm{mm}$ with their answers at questionnaires at eight weeks and one year concerning anal incontinence. A suggested control group would be women with perineal height or AVD above $20 \mathrm{~mm}$. 


\section{POPULÄRVETENSKAPLIG SAMMANFATTNING}

Avhandlingen beskriver en ny, strukturerad metod att undersöka förlossningsbristningar. Genom att känna på vävnaderna i mellangården och därefter göra ultraljud via slidan går det att undersöka om vävnaderna i mellangården och ändtarmens slutmuskler gått sönder. Undersökningen tar ungefär 3 minuter.

De senaste årens stora fokus på förlossningsbristningar och långsiktiga komplikationer efter dessa, från både patienter, vården, politiken och media har skapat en rädsla hos många blivande mödrar att föda barn vaginalt, för hur det blir efteråt och osäkerheten över om förlossningsvården kan ta hand om de förlossningsbristningar de kan få.

En förlossningsbristning bedöms efter vilka vävnader som gått sönder, från grad 1 till 4:

Grad 1. Slemhinnan i slidan har gått sönder.

Grad 2: Bristningen går ned i mellangården, som är området mellan slidan och ändtarmen. Bristningen kan vara ytlig eller gå längre ned i bäckenbotten, men ändtarmens slutmuskler är inte inblandade.

Människan har två slutmuskler, en yttre och en inre. Den yttre är relativt lätt att se och är själva "knipmuskeln". Den inre är svårare att se, då den är blek och tunn, och styrs inte av viljan.

Grad 3: Ändtarmens slutmuskler är trasiga. Läkaren skall då bedöma i vilken utsträckning slutmusklerna är skadade, och om det är den ena eller båda.

Grad 4: Bristningen går ned i ändtarmens slemhinna. Detta är en ovanlig form av bristning.

Hur ofta grad 3 och 4-bristningar inträffar följs på varje sjukhus och av Socialstyrelsen. Under 2017 fick 5,2\% av kvinnorna som födde sitt första barn en sådan bristning, och 1,3\% av kvinnorna som fött barn tidigare.

I avhandlingen undersöks möjligheten att på ett strukturerat sätt undersöka förlossningsbristningarna genom att känna i mellangården med fingertopparna, bedöma höjden mellan botten av bristningen och 
ändtarmen och undersöka området med ultraljud från slidan för att se om slutmusklerna till ändtarmen gått sönder.

Tills stor del har forskningen tidigare inom detta fält undersökt förlossningsbristningar i efterhand, hos kvinnor som har besvär. Avhandlingens metoder är menade att genomföras direkt efter förlossningen och innan bristningen repareras.

Den första studien undersöker metoden att göra ultraljud av bäckenbotten, hur fort den går att lära ut till vårdpersonal som tidigare är vana att göra ultraljud, samt hur väl måtten överensstämmer när två olika undersökare gör ultraljud på samma kvinna. Detta gjordes för att få veta om metoden är användbar av gynekologer, förlossningsläkare och barnmorskor, och om mätresultaten går att lita på. Den visade att det tar fem patientfall innan en ny person lärt sig metoden, och att undersökningsresultaten därefter stämmer nästan exakt överens.

Den andra studien syftar till att undersöka om ultraljud av en förlossningsbristning överensstämmer med det barnmorskan eller läkaren känner i vävnaden när bristningen undersöks. Detta gjordes genom att undersöka 150 kvinnor vid Universitetssjukhuset i Linköping. som precis fått sitt första barn. Studien gjordes genom att känna på vävnaden mellan bristningens botten och tarmen, undersöka den med ultraljud och jämföra måtten med den gradering av förlossningsbristning som gjordes innan bristningen syddes ihop. Studien visade att det som kändes i mellangården, väl stämde överens med det mått som kunde mätas med ultraljud. Om måttet av ultraljudsmätningen var lågt var det också fler kvinnor som fick bristningen graderad till grad 3. Om mellangårdsmåttet vid undersökningen var mer än $2 \mathrm{~cm}$, var risken för skada på ändtarmens slutmuskler låg. Detta gör att dessa undersökningar kan komplettera den vanliga undersökningen av förlossningsbristningar i praktiken.

Den tredje studien undersökte vad som ger en ökad risk för skador på inre slutmuskeln. Den är svår att se, men är viktig att hitta direkt efter förlossningen, då den annars drar ihop sig och förtvinar. Den inre slutmuskeln har till uppgift att hålla tillbaka gas och avföring, men hjälper också kroppen att hålla skillnad på om det är gas eller avföring som ligger 
längst ned i tarmen. Det kan leda till stort handikapp i vardagen om skador på inre slutmuskeln inte repareras direkt efter förlossningen.

Undersökningen baserar sitt material på 3333 kvinnor med slutmuskelskada registrerade i det nationella svenska Bristningsregistret mellan 2014 och 2018. Av de kvinnor som har fătt en skada på yttre slutmuskeln kunde konstateras att drygt en tredjedel även hade en skada på inre slutmuskeln. Ett barn föds oftast med armarna läng kroppen. Om barnet istället föds med armen eller handen bredvid huvudet fördubblas risken för skada på inre slutmuskeln. Likaså är risken större om avståndet $\mathrm{i}$ mellangården är kortare än $1 \mathrm{~cm}$ direkt efter barnet fötts. Detta är inte något som går att förebygga under förlossningen, men skall ses som varningssignaler till förlossningspersonalen.

I den fjärde studien undersöks hur den nya metoden att bedöma förlossningsbristningar som beskrivits ovan, kan införas vid en förlossningsavdelning. Studien undersöker vilka metoder som använts avseende utbildning, kommunikation och feedback till personalen och huruvida detta gjort att metoden använts till de kvinnor som kan ha nytta av den. Resultatet visar att i kombination med den obligatoriska nätutbildningen Bäckenbottenutbildning.se används metoden i större utsträckning fem år efter införandet.

Sammanfattningsvis kan avhandlingens resultat bidra till att underlätta för strukturerad diagnostik av förlossningsbristningar. Fortsatt forskning behövs för att undersöka hur detta långsiktigt påverkar kvinnor med förlossningsbristningar. 


\section{ACKNOWLEDGEMENTS}

I would like to thank all of the people around me who, with their knowledge, personalities and inspiration have contributed to my time as a $\mathrm{PhD}$-student. I am very grateful to you all. I would like to thank:

My main supervisor, Professor Marie Blomberg. Your straight communication, consideration and never-ending curiosity has taught me that you don't do research because you have to, but because it is so exciting. Thanks for the contagious science-virus!

My co-supervisor, Dr. Eva Uustal. You paint with the wide brushes; question establish facts and are always brave. Your visionary views, experience and knowledge about the pelvic floor are extraordinary.

My co-supervisor in implementation science, Professor Siw Carlfjord. You have, with your infinite patience, gently shown me the implementation way without ever making me feel stupid.

My fantastic colleagues at the Department of Obstetrics and Gynecology at Linköping University Hospital. For making it fun to go to work, creating a friendly developmental climate and for ongoing discussions. The team is unbeatable.

Everyone at the maternity ward, Linköping University Hospital. For making the greatest job in the world even better every single day. And for every time, day and night, you have scuffled the ultrasound machine through the corridors.

Dr. Ninnie Borendal Wodlin, Dr Gabriella Falk, Professor Mats Hammar, Professor Ann Josefsson, Associate Professor Caroline Lilliecreutz, Professor Gunilla Sydsjö and Dr Madelene Wedin for your wise reflections and comments on the thesis and manuscripts.

Dr Ninnie Borendal Wodlin, Associate Professor Elizabeth Nedstrand, Dr Annika Jeppsson, Dr Charlotte Ginstman and Dr Kristina Kernell for giving me the time and practical opportunity to write the thesis.

Lars Valter - for making statistics exciting and understandable. You have shown me how statistics relates to the rest of the world. Explaining what I really meant to you might be the hardest thing I've done during this time. 
Our research group FOPP - for unpretentious sharing of knowledge and unstoppable Friday night research geeking.

My co-PhD-students during the research courses. For all the sharing and discussing.

My friends around Sweden and the world - for showing me other parts of the world than I can reach and for seeing things differently than I do.

Maria Randjelovic - for making life coaching an extreme sport. And for friendship. And for borrowing your couch countless nights. And for many other things.

My father-in-law, Hans Vaerneus, for showing me what a dissertation might mean. And my mother-in-law Gun Vaerneus, for always being positive and supportive.

My brother-in-law Alf Vaerneus and sister-in-law Jessica Wadstrand - for intense discussions, wise judgement and honesty.

My brothers, David and Pontus, the best body guards I've ever had. And my sister -in-law Anna-Linnea, the closest a sister I'll get.

My mother, Ulla Pihl-Svenson - for my self-esteem. For giving me advice when I ask for it, and for your support when I do the opposite.

My father, Rolf Svensson. You are the most kind-hearted there is, and the best clinician and role-model I've met.

Ebba, Samuel, Nora and Stina, Axel, Agnes, Måns and Nils - the best team ever. To take part of your clever solutions, imaginative initiatives and brave adventures is the most fabulous and important thing I know. In Swedish - Det bästa teamet. Att se era finurliga lösningar, otippade initiativ och modiga äventyr $i$ stort och smått är det härligaste och viktigaste jag vet.

Anders - for uncompromised joy and confidence. You are my best everyday and my greatest adventure. 


\section{REFERENCES}

1. Bornemeier WC. Sphincter protecting hemorrhoidectomy. Am J Proctol. 1960;11:48-52.

2. Andrews V, Sultan AH, Thakar R, Jones PW. Occult anal sphincter injuries--myth or reality? BJOG. 2006;113(2):195-200.

3. $\quad$ Edqvist M, Hildingsson I, Mollberg M, Lundgren I, Lindgren $\mathrm{H}$.

Midwives' Management during the Second Stage of Labor in Relation to Second-

Degree Tears-An Experimental Study. Birth. 2017;44(1):86-94.

4. Försäkringsbolag LÖ. Bäckenbottenutbildning

www.backenbottenutbildning.se2017 [Available from: www.backenbottenutbildning.se. 5. Roos AM, Thakar R, Sultan AH. Outcome of primary repair of obstetric anal sphincter injuries (OASIS): does the grade of tear matter? Ultrasound Obstet Gynecol. 2010;36(3):368-74.

6. Kumar L, Emmanuel A. Internal anal sphincter: Clinical perspective. Surgeon. 2017;15(4):211-26.

7. Organization WH. International Classification of Disease 2015 [Available from: http://www.who.int/classifications/icd/en/.

8. Welfare SNBoHa. Statistical Database 2018 [Available from:

http://www.socialstyrelsen.se/statistik/statistikdatabas/graviditeter-

forlossningarochnyfodda.

9. Graviditetsregistret. Graviditetsregistret 2019 [Available from:

www.graviditetsregistret.se.

10. Stein TA, DeLancey JO. Structure of the perineal membrane in females: gross and microscopic anatomy. Obstet Gynecol. 2008;111(3):686-93.

11. Soga H, Nagata I, Murakami G, Yajima T, Takenaka A, Fujisawa M, et al. A histotopographic study of the perineal body in elderly women: the surgical applicability of novel histological findings. Int Urogynecol J Pelvic Floor Dysfunct. 2007; 18(12):1423-30.

12. Wagenlehner FM, Del Amo E, Santoro GA, Petros P. Live anatomy of the perineal body in patients with third-degree rectocele. Colorectal Dis. 2013;15(11):141622.

13. SBU. Analsfinkterskador vid förlossning.; 2016 2016-04-29. Contract No.: 978-91-85413-92-8.

14. Fornell EU, Matthiesen L, Sjodahl R, Berg G. Obstetric anal sphincter injury ten years after: subjective and objective long term effects. BJOG : an international journal of obstetrics and gynaecology. 2005;112(3):312-6.

15. McLeod NL, Gilmour DT, Joseph KS, Farrell SA, Luther ER. Trends in major risk factors for anal sphincter lacerations: a 10-year study. J Obstet Gynaecol Can. 2003;25(7):586-93. 

et al. Operative vaginal delivery and midline episiotomy: a bad combination for the perineum. Am J Obstet Gynecol. 2006;195(3):749-54.

17. Shiono P, Klebanoff MA, Carey JC. Midline episiotomies: more harm than good? Obstet Gynecol. 1990;75(5):765-70.

18. ACOG Practice Bulletin No. 198 Summary: Prevention and Management of Obstetric Lacerations at Vaginal Delivery. Obstet Gynecol. 2018;132(3):795-7.

19. Gynaecologists RCoOa. The Management of Third- and Fourth-Degree Perineal Tears 2015 [3:[Available from: https://www.rcog.org.uk/globalassets/documents/guidelines/gtg-29.pdf.

20. Williams A, Tincello DG, White S, Adams EJ, Alfirevic Z, Richmond $\mathrm{DH}$. Risk scoring system for prediction of obstetric anal sphincter injury. BJOG. 2005;112(8):1066-9.

21. Faltin DL, Sangalli MR, Roche B, Floris L, Boulvain M, Weil A. Does a second delivery increase the risk of anal incontinence? BJOG. 2001;108(7):684-8. 22. Deering SH, Carlson N, Stitely M, Allaire AD, Satin AJ. Perineal body length and lacerations at delivery. The Journal of reproductive medicine. 2004;49(4):306-10.

23. Baghestan E, Irgens LM, Bordahl PE, Rasmussen S. Familial risk of obstetric anal sphincter injuries: registry-based cohort study. BJOG. 2013;120(7):831-7. 24. Gurol-Urganci I, Cromwell DA, Edozien LC, Mahmood TA, Adams EJ, Richmond DH, et al. Third- and fourth-degree perineal tears among primiparous women in England between 2000 and 2012: time trends and risk factors. BJOG.

2013;120(12):1516-25.

25. Geller EJ, Robinson BL, Matthews CA, Celauro KP, Dunivan GC, Crane $\mathrm{AK}$, et al. Perineal body length as a risk factor for ultrasound-diagnosed anal sphincter tear at first delivery. Int Urogynecol J. 2014;25(5):631-6.

26. Pergialiotis V, Vlachos D, Protopapas A, Pappa K, Vlachos G. Risk factors for severe perineal lacerations during childbirth. Int J Gynaecol Obstet. 2014;125(1):6-14.

27. Simic M, Cnattingius S, Petersson G, Sandstrom A, Stephansson O. Duration of second stage of labor and instrumental delivery as risk factors for severe perineal lacerations: population-based study. BMC pregnancy and childbirth. 2017;17(1):72.

28. Ramm O, Woo VG, Hung YY, Chen HC, Ritterman Weintraub ML. Risk Factors for the Development of Obstetric Anal Sphincter Injuries in Modern Obstetric Practice. Obstet Gynecol. 2018;131(2):290-6.

29. Eisenberg VH, Valsky DV, Yagel S. Transperineal ultrasound assessment of the anal sphincter after obstetric anal sphincter injury (OASI). Ultrasound Obstet Gynecol. 2019;53(2):158-65.

30. Dudding TC, Vaizey CJ, Kamm MA. Obstetric anal sphincter injury: incidence, risk factors, and management. Annals of surgery. 2008;247(2):224-37. 31. Signorello LB, Harlow BL, Chekos AK, Repke JT. Postpartum sexual functioning and its relationship to perineal trauma: a retrospective cohort study of 
primiparous women. American journal of obstetrics and gynecology. 2001;184(5):8818; discussion 8-90.

32. Varma MG, Brown JS, Creasman JM, Thom DH, Van Den Eeden SK, Beattie MS, et al. Fecal incontinence in females older than aged 40 years: who is at risk? Diseases of the colon and rectum. 2006;49(6):841-51.

33. Mous M, Muller SA, de Leeuw JW. Long-term effects of anal sphincter rupture during vaginal delivery: faecal incontinence and sexual complaints. BJOG. 2008;115(2):234-8.

34. Lo J, Osterweil P, Li H, Mori T, Eden KB, Guise JM. Quality of life in women with postpartum anal incontinence. Obstet Gynecol. 2010;115(4):809-14.

35. LaCross A, Groff M, Smaldone A. Obstetric anal sphincter injury and anal incontinence following vaginal birth: a systematic review and meta-analysis. $\mathrm{J}$ Midwifery Womens Health. 2015;60(1):37-47.

36. Oberwalder M, Connor J, Wexner SD. Meta-analysis to determine the incidence of obstetric anal sphincter damage. The British journal of surgery. 2003;90(11):1333-7.

37. Starck M, Bohe M, Valentin L. Results of endosonographic imaging of the anal sphincter 2-7 days after primary repair of third- or fourth-degree obstetric sphincter tears. Ultrasound Obstet Gynecol. 2003;22(6):609-15.

38. Andrews V, Thakar R, Sultan AH. Structured hands-on training in repair of obstetric anal sphincter injuries (OASIS): an audit of clinical practice. Int Urogynecol J Pelvic Floor Dysfunct. 2009;20(2):193-9.

39. Groom KM, Paterson-Brown S. Can we improve on the diagnosis of third degree tears? (0301-2115 (Print)).

40. Starck M, Bohe M, Valentin L. The extent of endosonographic anal sphincter defects after primary repair of obstetric sphincter tears increases over time and is related to anal incontinence. Ultrasound Obstet Gynecol. 2006;27(2):188-97.

41. Sioutis D, Thakar R, Sultan AH. Overdiagnosis and rising rate of obstetric anal sphincter injuries (OASIS): time for reappraisal. Ultrasound Obstet Gynecol. 2017;50(5):642-7.

42. Mahony R, Behan M, Daly L, Kirwan C, O'Herlihy C, O'Connell PR. Internal anal sphincter defect influences continence outcome following obstetric anal sphincter injury. Am J Obstet Gynecol. 2007;196(3):217.e1-5.

43. Roos AM, Abdool Z, Sultan AH, Thakar R. The diagnostic accuracy of endovaginal and transperineal ultrasound for detecting anal sphincter defects: The PREDICT study. Clinical radiology. 2011;66(7):597-604.

44. Turel FD, Langer S, Shek KL, Dietz HP. Medium- to Long-term Followup of Obstetric Anal Sphincter Injury. Diseases of the colon and rectum. 2019;62(3):348-56.

45. Sultan AH, Monga AK, Kumar D, Stanton SL. Primary repair of obstetric anal sphincter rupture using the overlap technique. British journal of obstetrics and gynaecology. 1999;106(4):318-23.

46. Harvey MA, Pierce M, Alter JE, Chou Q, Diamond P, Epp A, et al. Obstetrical Anal Sphincter Injuries (OASIS): Prevention, Recognition, and Repair. 
Journal of obstetrics and gynaecology Canada : JOGC $=$ Journal d'obstetrique et gynecologie du Canada : JOGC. 2015;37(12):1131-48.

47. Shobeiri SA, Nolan TE, Yordan-Jovet R, Echols KT, Chesson RR. Digital examination compared to trans-perineal ultrasound for the evaluation of anal sphincter repair. Int J Gynaecol Obstet. 2002;78(1):31-6.

48. Faltin DL, Boulvain M, Stan C, Epiney M, Weil A, Irion O. Intraobserver and interobserver agreement in the diagnosis of anal sphincter tears by postpartum endosonography. Ultrasound Obstet Gynecol. 2003;21(4):375-7.

49. Faltin DL, Boulvain M, Floris LA, Irion O. Diagnosis of anal sphincter tears to prevent fecal incontinence: a randomized controlled trial. Obstet Gynecol. 2005;106(1):6-13.

50. Walsh KA, Grivell RM. Use of endoanal ultrasound for reducing the risk of complications related to anal sphincter injury after vaginal birth. Cochrane Database Syst Rev. 2015(10):CD010826.

51. Santoro GA, Wieczorek AP, Dietz HP, Mellgren A, Sultan AH, Shobeiri SA, et al. State of the art: an integrated approach to pelvic floor ultrasonography. Ultrasound Obstet Gynecol. 2011;37(4):381-96.

52. Dietz HP. Exoanal Imaging of the Anal Sphincters. J Ultrasound Med. 2018;37(1):263-80.

53. Peschers UM, DeLancey JO, Schaer GN, Schuessler B. Exoanal ultrasound of the anal sphincter: normal anatomy and sphincter defects. British journal of obstetrics and gynaecology. 1997;104(9):999-1003.

54. Ozyurt S, Aksoy H, Gedikbasi A, Yildirim G, Aksoy U, Acmaz G, et al. Screening occult anal sphincter injuries in primigravid women after vaginal delivery with transperineal use of vaginal probe: a prospective, randomized controlled trial. Archives of gynecology and obstetrics. 2015;292(4):853-9.

55. Timor-Tritsch IE, Monteagudo A, Smilen SW, Porges RF, Avizova E.

Simple ultrasound evaluation of the anal sphincter in female patients using a transvaginal transducer. Ultrasound Obstet Gynecol. 2005;25(2):177-83.

56. Frudinger A, Bartram CI, Kamm MA. Transvaginal versus anal endosonography for detecting damage to the anal sphincter. AJR American journal of roentgenology. 1997;168(6):1435-8.

57. Poen AC, Felt-Bersma RJ, Cuesta MA, Meuwissen GM. Vaginal endosonography of the anal sphincter complex is important in the assessment of faecal incontinence and perianal sepsis. The British journal of surgery. 1998;85(3):359-63.

58. Stewart LK, Wilson SR. Transvaginal sonography of the anal sphincter: reliable, or not? AJR American journal of roentgenology. 1999;173(1):179-85.

59. Berton F, Gola G, Wilson SR. Sonography of benign conditions of the anal canal: an update. AJR American journal of roentgenology. 2007;189(4):765-73. 60. Orno AK, Marsal K, Herbst A. Ultrasonographic anatomy of perineal structures during pregnancy and immediately following obstetric injury. Ultrasound Obstet Gynecol. 2008;32(4):527-34.

61. Yagel S Fau - Valsky DV, Valsky DV, Valsky DV, Messing B Fau Petkova R, Petkova R Fau - Savchev S, Savchev S Fau - Rosenak D, et al. Three- 
dimensional transperineal ultrasonography for evaluation of the anal sphincter complex: another dimension in understanding peripartum sphincter trauma Postpartum evaluation of the anal sphincter by transperineal three-dimensional ultrasound in primiparous women after vaginal delivery and following surgical repair of third-degree tears by the overlapping technique. (0960-7692 (Print)).

62. Roche B, Deleaval J, Fransioli A, Marti MC. Comparison of transanal and external perineal ultrasonography. Eur Radiol. 2001;11(7):1165-70.

63. Maslovitz S, Jaffa A, Levin I, Almog B, Lessing JB, Wolman I. The clinical significance of postpartum transperineal ultrasound of the anal sphincter. European journal of obstetrics, gynecology, and reproductive biology. 2007;134(1):1159.

64. Ros C, Martinez-Franco E, Wozniak MM, Cassado J, Santoro GA, Elias $\mathrm{N}$, et al. Postpartum two- and three-dimensional ultrasound evaluation of anal sphincter complex in women with obstetric anal sphincter injury. Ultrasound Obstet Gynecol. 2017;49(4):508-14.

65. Norderval S, Dehli T Fau - Vonen B, Vonen B. Three-dimensional endoanal ultrasonography: intraobserver and interobserver agreement using scoring systems for classification of anal sphincter defects. (1469-0705 (Electronic)).

66. Starck M, Bohe M, Fortling B, Valentin L. Endosonography of the anal sphincter in women of different ages and parity. Ultrasound Obstet Gynecol. 2005;25(2):169-76.

67. Santoro GA, Wieczorek AP, Shobeiri SA, Mueller ER, Pilat J, Stankiewicz A, et al. Interobserver and interdisciplinary reproducibility of 3D endovaginal ultrasound assessment of pelvic floor anatomy. Int Urogynecol J. 2011;22(1):53-9.

68. Valsky DV, Messing B, Petkova R, Savchev S, Rosenak D, HochnerCelnikier D, et al. Postpartum evaluation of the anal sphincter by transperineal threedimensional ultrasound in primiparous women after vaginal delivery and following surgical repair of third-degree tears by the overlapping technique. Ultrasound Obstet Gynecol. 2007;29(2):195-204.

69. Regions SAoLAa. The Swedish National Quality Registry of Gynecological Surgery www2.gynop.se1997 [

70. Laine K, Gissler M, Pirhonen J. Changing incidence of anal sphincter tears in four Nordic countries through the last decades. European journal of obstetrics, gynecology, and reproductive biology. 2009;146(1):71-5.

71. Committee on Practice B-O. ACOG Practice Bulletin No. 198: Prevention and Management of Obstetric Lacerations at Vaginal Delivery. Obstet Gynecol. 2018;132(3):e87-e102.

72. Bauer MS, Damschroder L, Hagedorn H, Smith J, Kilbourne AM. An introduction to implementation science for the non-specialist. BMC Psychol. 2015;3:32. 73. Balas EA, Boren SA. Managing Clinical Knowledge for Health Care Improvement. Yearb Med Inform. 2000(1):65-70. 

question: understanding time lags in translational research. Journal of the Royal Society of Medicine. 2011;104(12):510-20.

75. Rabin BA, Brownson RC, Haire-Joshu D, Kreuter MW, Weaver NL. A glossary for dissemination and implementation research in health. Journal of public health management and practice : JPHMP. 2008;14(2):117-23.

76. Damschroder LJ, Aron DC, Keith RE, Kirsh SR, Alexander JA, Lowery

JC. Fostering implementation of health services research findings into practice: a consolidated framework for advancing implementation science. Implement Sci. 2009;4:50.

77. Alberts B, Kirschner MW, Tilghman S, Varmus H. Rescuing US biomedical research from its systemic flaws. Proc Natl Acad Sci U S A. 2014;111(16):5773-7.

78. Damschroder LJ, Moin T, Datta SK, Reardon CM, Steinle N, Weinreb J, et al. Implementation and evaluation of the VA DPP clinical demonstration: protocol for a multi-site non-randomized hybrid effectiveness-implementation type III trial. Implement Sci. 2015;10:68.

79. Keith RE, Crosson JC, O'Malley AS, Cromp D, Taylor EF. Using the Consolidated Framework for Implementation Research (CFIR) to produce actionable findings: a rapid-cycle evaluation approach to improving implementation. Implement Sci. 2017;12(1):15.

80. Soi C, Gimbel S, Chilundo B, Muchanga V, Matsinhe L, Sherr K. Human papillomavirus vaccine delivery in Mozambique: identification of implementation performance drivers using the Consolidated Framework for Implementation Research (CFIR). Implement Sci. 2018;13(1):151.

81. Powell BJ, Waltz TJ, Chinman MJ, Damschroder LJ, Smith JL, Matthieu $\mathrm{MM}$, et al. A refined compilation of implementation strategies: results from the Expert Recommendations for Implementing Change (ERIC) project. Implement Sci. 2015;10:21.

82. Surgery. TNQRoG. Gynop.se/home/about-gynop/ 2019 [2019-06-05]. Available from: www2.gynop.se/home.

83. Cane J, O'Connor D, Michie S. Validation of the theoretical domains framework for use in behaviour change and implementation research. Implement Sci. 2012;7:37.

84. Waltz TJ, Powell BJ, Matthieu MM, Damschroder LJ, Chinman MJ, Smith JL, et al. Use of concept mapping to characterize relationships among implementation strategies and assess their feasibility and importance: results from the Expert Recommendations for Implementing Change (ERIC) study. Implement Sci. 2015;10:109.

85 .

Betty R. Kirkwood JACS. Essential Medical Statistics: Blackwell Science; 2003.

86. Field A. Discovering Statistics using IBM SPSS Statistics. 4 ed: SAGE; 2015. 

overview. Biochem Med (Zagreb). 2014;24(2):199-210.

88. Messerlian C, Basso O. Cohort studies in the context of obstetric and gynecologic research: a methodologic overview. Acta Obstet Gynecol Scand. 2018;97(4):371-9.

89. Nielsen P. Implementering av evidensbaserad praktik: Gleerups; 2014 90. van Delft K, Schwertner-Tiepelmann N, Thakar R, Sultan AH.

Recruitment of pregnant women in research. Journal of obstetrics and gynaecology : the journal of the Institute of Obstetrics and Gynaecology. 2013;33(5):442-6.

91. Oberwalder M, Dinnewitzer A Fau - Baig MK, Baig Mk Fau - Thaler K, Thaler K Fau - Cotman K, Cotman K Fau - Nogueras JJ, Nogueras Jj Fau - Weiss EG, et al. The association between late-onset fecal incontinence and obstetric anal sphincter defects Anal ultrasound and endosonographic measurement of perineal body thickness: a new evaluation for fecal incontinence in females Meta-analysis to determine the incidence of obstetric anal sphincter damage. (0004-0010 (Print)).

92. Tetzschner T, Sorensen M, Lose G, Christiansen J. Anal and urinary incontinence in women with obstetric anal sphincter rupture. British journal of obstetrics and gynaecology. 1996;103(10):1034-40.

93. Karoui S, Savoye-Collet C, Koning E, Leroi AM, Denis P. Prevalence of anal sphincter defects revealed by sonography in 335 incontinent patients and 115 continent patients. AJR American journal of roentgenology. 1999;173(2):389-92.

94. Abramowitz L, Sobhani I, Ganansia R, Vuagnat A, Benifla JL, Darai E, et al. Are sphincter defects the cause of anal incontinence after vaginal delivery? Results of a prospective study. Diseases of the colon and rectum. 2000;43(5):590-6; discussion 6-8.

95. De Leeuw JW, Vierhout ME, Struijk PC, Hop WCJ, Wallenburg HCS. Anal sphincter damage after vaginal delivery: functional outcome and risk factors for fecal incontinence. Acta Obstetricia et Gynecologica Scandinavica. 2001;80(9):830-4. 96. Norderval S, Oian P, Revhaug A, Vonen B. Anal incontinence after obstetric sphincter tears: outcome of anatomic primary repairs. Diseases of the colon and rectum. 2005;48(5):1055-61.

97. Faltin DL, Otero M, Petignat P, Sangalli MR, Floris LA, Boulvain M, et al. Women's health 18 years after rupture of the anal sphincter during childbirth: I. Fecal incontinence. Am J Obstet Gynecol. 2006;194(5):1255-9.

98. Laine K, Skjeldestad FE, Sanda B, Horne H, Spydslaug A, Staff AC. Prevalence and risk factors for anal incontinence after obstetric anal sphincter rupture. Acta Obstet Gynecol Scand. 2011;90(4):319-24. 


\section{Papers}

The papers associated with this thesis have been removed for copyright reasons. For more details about these see:

http://urn.kb.se/resolve?urn=urn:nbn:se:liu:diva-162580 


\section{FACULTY OF MEDICINE AND HEALTH SCIENCES}

Linköping University Medical Dissertation No. 1715, 2020

Department of Clinical and Experimental Medicine

Linköping University

SE-581 83 Linköping, Sweden

wWW.liu.se 